\title{
(DES)CONSTRUINDO O DISCURSO ELEITORAL: O PRIMEIRO TURNO DAS ELEIÇÕES MUNICIPAIS MAJORITÁRIAS EM CURITIBA NO ANO 2000'
}

Rosa Moura

\author{
Thaís Kornin
}

\begin{abstract}
RESUMO
O pensamento único vem prevalecendo na escolha e adoção de instrumentos e políticas urbanas, conduzido pela opção de inserir as cidades no processo de reestruturação produtiva, em cumprimento aos requisitos impostos pelo modelo globalizante. Como uma ação naturalizada, esse procedimento espelha, de fato, intenções alheias ao lugar, e que são interiorizadas no imaginário da população, como um consenso. Que resultados tais estratégias provocam na produção do espaço urbano e no exercício da cidadania, e como foram incorporadas e veiculadas no discurso eleitoral do primeiro turno das eleições municipais majoritárias em Curitiba no ano 2000? Este ensaio vai em busca de respostas a essa questão.
\end{abstract}

PALAVRAS-CHAVE: Curitiba; eleições municipais; discurso eleitoral; planejamento urbano; city marketing.

“[...] O discurso não é simplesmente aquilo que traduz as lutas ou os sistemas de dominação, mas aquilo por que, pelo que se luta, o poder do qual nos queremos apoderar".

Michel Foucault, A ordem do discurso.

\section{INTRODUÇÃO}

Que percepção de mundo, que leituras da problemática urbana permeiam o discurso eleitoral? Que ideologia o codifica?

Carregado de símbolos e de interesses, o discurso cumpre papel determinante na dinâmica cotidiana de produção e reprodução do espaço, interferindo no comportamento dos agentes intervenientes nessa dinâmica e exibindo suas decisões. Na materialidade das suas palavras,

1 Artigo originalmente apresentado na sessão "Metropolização, centralidade e agentes urbanos" durante o Simpósio Cidade e poder, realizado entre 23 e 24 de abril de 2001 na Universidade Federal do Paraná, promovido pela Revista de Sociologia e Política e pelo Grupo de Estudos Cidade, Poder e Sociedade, sob coordenação do Prof. Dr. Nelson Rosário de Souza. Esta leitura decorre do compromisso político das autoras como cidadãs curitibanas, não refletindo absolutamente a atividade desenvolvida em sua instituição de origem. As autoras agradecem a Fernanda Sánchez e Marise Manoel pela leitura crítica e contribuições enriquecedoras ao trabalho. imagens de uma cidade existente ou por vir são construídas a partir de interpretações do urbano, imagens que são assumidas enquanto realidade. Nessa condição, o discurso eleitoral adquire um papel ainda mais relevante, pois, ao mesmo tempo em que se articula a partir de uma visão da cidade, tecendo proposições para seu futuro, vai moldando o cidadão, ajustando-o a essa imagem de cidade que passa a compor.

Entender essa prática discursiva ajuda a reencontrar os elos existentes entre o "local" e o "global", entre a adequação das propostas a demandas particulares e uma intencionalidade externa, comandante. Mais que isso, pode explicitar os conflitos e as contradições que os interesses hegemônicos tecem sob a imagem de cidades-modelo - no caso de Curitiba, uma imagem não desprezada por nenhum dos candidatos.

Esse é o motivo que impulsiona esta reflexão sobre as falas dos candidatos do primeiro turno à sucessão administrativa de Curitiba para o período 2001 a 2004. São candidatos cujos perfis mesclam 
tons de crítica, às vezes contundentes, a proposições animadas ou reflexões introspectivas; viagens quiméricas através de recantos lúdicos da cidade a frases de efeito (v. Anexo 1). A opção por esse turno eleitoral deve-se ao entendimento de que é nessa fase inicial da campanha que a pluralidade de interesses é mais explícita, dado que ainda não se configuraram polarizações entre candidaturas. É uma fase em que mais se colocam posições do que se desmontam postulados do adversário - o que ostensivamente passa a ocorrer na disputa pelo segundo turno.

É importante salientar que, embora o horário eleitoral seja gratuito, os programas usam recursos de linguagem televisiva que envolvem somas elevadas de investimentos para contratação de serviços especializados que transformem a proposta política em uma peça de entretenimento. Sobre essa relação política-televisão, Bourdieu observa que, em "um universo dominado pelo temor de ser entediante e pela preocupação (quase pânico) de divertir a qualquer preço, a política está condenada a aparecer como um assunto ingrato, que se exclui tanto quanto possível dos horários de grande audiência, um espetáculo pouco excitante, ou mesmo deprimente e difícil de tratar, que é preciso tornar interessante a qualquer preço" (BOURDIEU, 1998, p. 95).

Isso implica laboriosas construções que despertem o eleitor-espectador e exponham situações com as quais ele encontre um mínimo de identidade $^{2}$. Além da pândega a ser criada, é também preciso compor o candidato para que se torne um produto aceito, consumível pelo voto. Os resultados obtidos colocam em evidência as desigualdades entre as partes, pois, mesmo que o horário gratuito vise a ampliar e a universalizar o espaço de penetração do debate e a construção de uma agenda política, a assimetria entre os períodos de

2 Nesse sentido, sem grandes investimentos, o candidato Jamil Nakad, com um conjunto de frases de efeito, marcou principalmente o eleitorado jovem: "Ladrão? Chega de ladrão!”, "Chega de mamata! O circo já está montado e o palhaço continua sendo você!", "Chega dessa gente da reeleição. Eles cobram pedágio até pra fazer cocô", "Deixe de ser otário dessa gente. Chega dos mesmos!”, "Eles dão rasteira até em cobra", "Enquanto rico dança em Nova York, pobre dança o samba de um salário só”, "Ô coitado! Você acha graça? Mas o chupa-cabra continua chupando o sangue dos pobres”, dentre outras. tempo destinados aos candidatos e a eficácia do marketing político contratado reforçam o desequilíbrio de condições. Pesa sobre isso a ação paralela da mídia que, embora apresente-se como veículo imparcial de informação, acaba por abrir espaços seletivos a matérias que colocam em evidência apenas alguns candidatos.

Para garantir a eficácia de convencimento, os programas dividiram espaço na televisão com rápidos "comerciais" de forte conotação ideológica que, pela característica de veiculação de sua mensagem, tiveram grande penetração no imaginário do eleitor, consolidando ainda mais o jogo de representações e imagens construídas (Anexo 2).

\section{CURITIBA: A PROTAGONISTA}

No discurso eleitoral, a cidade é a protagonista. Cada candidato tece um roteiro para garantir um desempenho urbano que agrade ao público - o eleitorado. E cada roteiro vem carregado de interesses que podem ser ou a montagem de um espetáculo aberto e participativo, inserindo ativamente todos os cidadãos, ou uma função que se volta aos anseios únicos dos produtores, ou seja, dos agentes que a financiam, mas que busca a cumplicidade passiva dos espectadores - os moradores da cidade.

Não só os candidatos, mas principalmente segmentos de teóricos urbanos, concebem a cidade, nestes tempos de globalização, como protagonista, já que entendem que é ela quem determina o progresso econômico, o bem-estar social e a integração cultural de seus povos, tornando-se a verdadeira propulsora das ações cotidianas e dos relacionamentos externos (BORJA \& CASTELLS, 1996). Nessa ótica, o planejamento estratégico passou a ser a ferramenta mais adequada para materializar essa condição, capacitando a cidade a gerar respostas aos desafios da globalização.

Curitiba, desde os anos 70, implementa a estratégia de projeção da eficácia conquistada no planejamento e gestão urbanos, alicerçada nos mesmos elementos identificados como pilares do planejamento estratégico de cidades, que traz embutido o forte comprometimento com a economia de mercado, com a flexibilização produtiva e a adequação infra-estrutural, especialmente na organização e qualificação do espaço, requeridas pelos grandes empreendimentos - comprometimento notório na adequação da infra-estrutura, materializada em investimentos no sistema viário e de comunicações, e da norma jurídica, expressa 
em sua recém-aprovada Lei de uso do solo, para viabilizar os novos equipamentos comerciais, industriais e residenciais, inclusive em municípios vizinhos. Esse vínculo é resgatado no discurso eleitoral, tanto no intuito de seu reforço, quanto no de sua crítica.

O planejamento estratégico, como didaticamente expõe Vainer, "está estruturado basicamente na paradoxal articulação de três analogias: a cidade é uma mercadoria, a cidade é uma empresa, a cidade é uma pátria" (VAINER, 2000, p. 77). A primeira textualmente integra o discurso dos difusores dessa teoria e resulta de uma relação direta entre a configuração espacial urbana e a produção e reprodução do capital. Mais que isso, já é prática corrente na gestão urbana, o que explica o abusivo recurso do city marketing, desde há muito utilizado em Curitiba. A segunda analogia personifica a cidade como agente em competição, buscando aumentar, a qualquer custo, seu poder atrativo. A cidade deixa a forma passiva de objeto e assume a forma ativa de sujeito, ganhando nova identidade, a de empresa, e passando a competir no mercado de cidades. Tal analogia enfatiza a busca da agilidade e a transparência nas formas de gestão, com desburocratização dos processos, mas, na verdade, pressupõe a despolitização e produtivização da cidade. Ou seja, os "controles políticos são estranhos a um espaço social onde o que conta é a produtividade e a competitividade, e onde o que vale são os resultados" (idem, p. 90).

Essas analogias são facilitadas pela terceira: a unificação da sociedade em torno de um "projeto", a criação do consenso, a modelização, a geração de um "patriotismo da cidade" (Borja \& Forn, apud VAINER, 2000), que faz aparentar a inexistência de jogos de interesses ou conflitos peculiares à produção do espaço urbano e regional. Uma liderança carismática e individualizada - que elimina a esfera política local, a construção da cidadania - encarna a unidade, situando-se "acima dos partidos e paixões" e tornando-se o elemento estruturador do próprio projeto, do exercício do projeto empresarial. Sob domínio das mesmas classes rentistas, a "fabricação de consensos", a ação "em concerto", é na verdade "uma fábrica por excelência de ideologias, portanto: do território, da comunidade, do civismo etc. Mas, sobretudo, a fabulação de senso comum econômico [...]" (ARANTES, 2000, p. 27).

As três analogias cristalizam-se na prática do planejamento curitibano, compondo o discurso oficial da gestão urbana e, conseqüentemente, as mensagens da candidatura à reeleição. As bases das construções discursivas, que antecedem a construção das coisas, têm origem na ideologia hegemônica. Com isso, o uso da informação, de metáforas, de fabulações fortemente ideologizadas impõe-se na sociedade via produção de imagens e do imaginário, contribuindo fortemente para a construção de um pensamento único (SANTOS, 2000).

Esse pensamento único permeou a construção discursiva eleitoral, refletido nas facetas de produção de imagens e representações de uma cidade a ser renovada com proposições submissas a ordens expressas pelo próprio capital (empreendedor) ou às exigências de seus agentes financiadores. Apresentou-se, ao mesmo tempo, como o alvo da crítica dos opositores, e, nesse caso, decomposto tanto na denúncia de um modelo que, corrompido, apenas se sustenta nos efeitos especiais de sua virtualidade, quanto na perspectiva de uma mudança seletiva, porém não desideologizada, resgatando conquistas materiais e redirecionando finalidades sociais. Em ambas as situações, o discurso pôde ter transmitido a "ironia objetiva" lembrada por Arantes, na qual os candidatos poderiam estar convertendo "as melhores intenções no seu avesso, realizando, não por desvio mas por finalidade interna, o contrário do que prometiam" (ARANTES, 2000, p. 11).

Assim, a despeito das críticas, prevaleceu o respeito, a consolidação e/ou aperfeiçoamento do modelo-Curitiba - posto à prova na ocasião eleitoral -, construído à luz de um projeto políticoeconômico voltado a tornar a cidade competitiva, ou a construir a cidade-mercadoria. Em conseqüência (ou em prol de), emergiram inúmeras propostas de reestruturação urbana, pautadas na renovação de espaços públicos e privados a partir de parâmetros físicos e culturais globalizados, que poderiam resultar em lugares homogêneos, ou "não-lugares" (AUGÉ, 1994; BENKO, 1994), reproduzindo valores distantes da realidade própria da cidade, mas afetos a uma identidade mundializada e dominada pelo consumo.

O constante resgate da história e da eficácia do planejamento urbano de Curitiba, transformado ele mesmo em um modelo, de certo modo explicitou sua concepção - usual em tantas cidades - como instrumento de consolidação das relações com o mercado internacional, sujeito à lógica dos agentes financeiros multilaterais. Por sua vez, 
enalteceu a competitividade em vez da eqüidade, e as perspectivas economicamente promissoras, por ele abertas, em vez da legitimidade que deveria buscar por meio de políticas públicas voltadas aos interesses da sociedade ${ }^{3}$.

\section{II.1 IMAGENS E REPRESENTAÇÕES}

A gestão do espaço urbano é pautada fundamentalmente na produção de imagens que se convertem na própria realidade. Grupos dominantes perpetuam seu exercício de poder a partir de um jogo de representações, expresso em políticas, projetos e práticas de controle, buscando garantir a estabilidade social a partir do "convencimento" - ou da representação do interesse dominante como interesse comum da sociedade -, que por sua vez dá legitimidade a esse grupo do poder.

O urbanismo torna-se o modelador de tais representações, já que recria espaços comerciais, culturais e turísticos atrativos aos grandes investimentos. A veiculação de mensagens tornando sedutoras tais transformações produz uma subjetividade coletiva, exercendo um efeito esmorecedor da capacidade crítica dos cidadãos "seduzidos": "O urbanismo realizado está no centro da cena, a cidade tornada sujeito, o que em determinadas circunstâncias transforma os próprios cidadãos em meros figurantes, atores secundários de seu roteiro" (SÁNCHEZ, 1999, p. 27).

A produção da imagem urbana, apoiada nas técnicas do city marketing, além de promover o poder atrativo da cidade, volta-se a criar uma "solidariedade social", um "orgulho cívico", uma "lealdade" e uma "identidade local" pautados na despolitização da leitura da cidade pelo fascínio de sua modelização, o que permite a abertura de uma gama de mecanismos de controle social. A constituição de imagens-marca da cidade, filtradas pelos mecanismos da mídia, enfatiza uma positividade do espaço que passa a funcionar como diferenciador na esfera da produção (atração de investimentos) e na do consumo (cidade como

\footnotetext{
3 Há décadas otimizando as linhas de financiamento de agências multilaterais, especialmente do Banco Mundial, o planejamento de Curitiba viabilizou uma cidade cujos atributos infra-estruturais e de desenho urbano a tornam apta a competir no mercado internacional de cidades. Tal qualificação constituiu um espaço altamente seletivo, acentuando as desigualdades sócio-espaciais com sua área metropolitana.
}

produto), criando a cidade-espetáculo ${ }^{4}$, na qual se opera a produção de lugares-vitrine para uma cidadania embevecida (SÁNCHEZ, 1999).

A venda, pela mídia, da idéia de uma cidade próspera, obscurece problemas sociais e econômicos, assumidamente ignorados pelos meios de comunicação, pelos empreendedores, pelos gerentes urbanos, e até por grupos ditos de oposição, como forma de favorecer representantes desses segmentos - verdadeiros defensores do chamado "pensamento único". Essa opção faz que a imagem triunfe sobre a matéria (HARVEY, 1996).

Associada também ao "pensamento único" e ao consenso, a imagem da cidade-modelo minimiza as diferenças e os conflitos existentes, impondo seu modo de ver o mundo e moldando as condições para a ação dos grupos locais, no rastro da reprodução de uma intenção dos denominados “impulsos globais" (RIBEIRO, 1999).

Os gestores, que conferem a Curitiba o status de modelo, comprovam ter assumido com mestria esse papel: modelo em planejamento e gestão, em soluções urbanísticas, em transporte, em programas ambientais, em preservação de áreas verdes e reciclagem de resíduos. Esse modelo recebe sucessivas premiações internacionais e busca ser reproduzido por outras cidades. Em sua modelização, além das intervenções urbanísticas usualmente consagradas, os gestores incorporam os ditames globais, como, mais recentemente, o de enfatizar o exercício da gestão urbana voltada a otimizar a competitividade - condição necessária para sustentar o desenvolvimento numa economia global. Incluem-se nesse exercício a requalificação do desenho urbano, a valorização da atratividade a partir da identidade e qualidade ambiental e a organização funcional e tecnológica para a realização de negócios. Ao menos o discurso oficial passou também a valorizar a participação comunitária e o estabelecimento de parcerias entre o setor público e o privado. Cumpre-se, assim, o rol de quesitos da modelização, conforme pensadores e gestores internacionais (SÁNCHEZ \& MOURA, 1999).

\footnotetext{
4 Nesse sentido, é ilustrativa a campanha publicitária que une o Festival de Teatro à comemoração dos 308 anos da cidade. Um outdoor composto como um palco emoldurado por cortinas abertas mostra um casal abraçado e se entreolhando, com o Jardim Botânico ao fundo, como cenário, e a mensagem: "Há 308 anos, Curitiba é um grande espetáculo".
} 
Essa concepção fez que o urbanismo permanecesse no centro da cena das propostas de alguns candidatos, cristalizado em sua possibilidade atrativa. E mais: antecipando uma pressão sensível por parte da sociedade ou subordinada às exigências dos agentes financiadores multilaterais, as mesmas propostas já agregaram a participação da sociedade na definição ou detalhamento de projetos.

No jogo de representações do discurso eleitoral, o modelo Curitiba adquire diferentes conotações. Para o candidato à reeleição e que vem participando da contínua construção e consolidação da imagem de cidade-modelo, Cássio Taniguchi, ciente das críticas quanto às contradições sociais presentes na cidade e sua área metropolitana, o modelo, que se firma na solução de continuidade, vai além das práticas urbanísticas. Com imagens dos ícones locais, seu programa afirma: "Quem visita Curitiba vê bem mais que belas imagens". Entrevistas com turistas brasileiros enaltecem o padrão urbano e a qualidade de vida na cidade; em outro programa, rebate as críticas quanto a lacunas sociais: "Através de várias administrações bemsucedidas, somos referência na área social. Através dessa rede de solidariedade que foi criada ao longo desses anos todos e que hoje culmina nesta rede de serviços $[. .$.$] com tudo aquilo que uma$ cidade precisa dar aos seus habitantes". A personificação do espaço urbano como o lugar de todos, com o qual todos se identificam, torna artesanal essa representação:

"Curitiba, uma cidade que é um pouco de cada cidade. [Imagens de Curitiba que lembram ícones de Brasília, da Europa, de Salvador, do Oriente e do interior do Brasil.] Lugar onde ninguém se sente verdadeiramente longe de casa. [...] Curitiba é familiar e surpreendente. Dependendo do olhar, do ângulo, da luz, há sempre algo novo. [...] Quando se caminha, dá para entender como ela é diferente. Tudo começou com o fechamento do centro em vez da abertura de novas avenidas e viadutos [...] com a valorização das fachadas [...] caminhando, o povo pode observar velhas fachadas [...], com a oferta de novos equipamentos [imagens singelas de bancos de madeira, mesas de jogos de damas e xadrez], em vez de monumentos. [...] Tudo o que é feito aqui tem um toque especial da nossa gente".

Nessa ação artesanal, nada mais forte e convincente que a imagem de costureiras que bordam os nomes de cada bairro e emendam uns nos ou- tros, formando o mapa da cidade. E nada mais próprio que a extensão dos ícones dos modelos a esses bairros, como acena o Programa Nossa Rua: "ruas comerciais dos bairros equipadas para se transformarem em shoppings abertos [ao fundo imagens dos equipamentos similares aos do calçadão da Rua XV - floreiras, lugar para deixar crianças etc.], melhorar a infra-estrutura e organizar as ruas de comércio [rua dos calçados, ruas dos móveis etc.]. Melhorar os negócios para aumentar empregos".

Mas a simplicidade dá as mãos à tecnologia e renova a identidade urbana: com imagens processadas digitalmente, é mostrada "a pavimentação mudando a vida das pessoas"; "a rua volta a ser o lugar da convivência, do encontro". É exposto o Plano 2 000: calçadas nos dois lados dos 1000 $\mathrm{km}$ já pavimentados (Plano 1000 ), ciclovias, iluminação, lixeiras, sinalização para caminhadas, pontos de convivência, resultando na valorização dos imóveis, empregos nas obras, no comércio. Ações com "visão estratégica: promover, na prática, a inclusão social". Sob essa ótica, pretende-se consolidar a nova face da imagem da cidade-modelo, agora sob um "planejamento com vanguarda social", afinal, "toda a obra tem que ter garantia de vida melhor, de avanço social. Curitiba para o curitibano". A inserção do social no discurso se torna mais enfática no final da campanha. Num dos últimos programas, Marina Taniguchi, esposa de Cássio, fala dos projetos sociais da Prefeitura e, após o pedido de voto, preconiza: "Curitiba será cada vez mais exemplo de justiça social e respeito pelas pessoas".

Com os mesmos truques de computação gráfica, o programa eleitoral vai sucessivamente produzindo uma virtualidade sedutora: "Cássio transforma problemas em soluções". Mais que isso, vai subliminarmente minando a aceitação pelo eleitorado de candidatos opositores, como comprova a sequiência: "Bairro Novo, em menos de oito anos, casa própria, endereço e qualidade de vida para dezenas de famílias". Repentinamente, truques de computação cobrem as imagens do Bairro Novo com barracas de lonas pretas: "assim seria se a região, como antes, fosse dominada por aqueles que usam a invasão como regra e a lona preta como teto". E mais, num comercial do candidato, uma bandeira branca se transforma em vermelha à medida que se fala em off: "Nos últimos quatro anos, Curitiba viveu em paz. Atraiu investimentos, progrediu. Tornou-se humana e justa. Sem greves, 
sem tumultos, sem agitações. Você sabe como isto é importante. Agora imagine Curitiba dominada pela agressão, pela intolerância, pelo radicalismo político. Os curitibanos amam Curitiba e vão protegê-la [a última frase aparece em texto na tela para reforço da voz]".

$\mathrm{Na}$ mesma linha de que Curitiba está "sob ameaça", a campanha passa a compor um pesado jogo de simulações, associando os candidatos e partidos da oposição às lutas ("desordens") do MST. Voz em off afirma que Cássio é a favor da reforma agrária e que o programa Vilas Rurais, do governador Jaime Lerner, é a maneira mais eficiente e humana de fazer a reforma agrária. A mesma voz em off informa que "o Prefeito Cássio entende a luta do homem do campo, mas é contra a manipulação política que tira a legitimidade do movimento e incentiva a desordem e a violência". As imagens objetivas do acampamento do MST em frente ao Palácio Iguaçu dispersam-se num espectro subjetivo: mostram os elos dos opositores $^{5}$ com o MST, no íntimo ato de tomar chimarrão, enquanto anunciam a ameaça à ordem urbana, já que "os partidos e os políticos que sempre concordaram com o MST incentivam a invasão", e questionam o tom leve de suas campanhas: "A população de Curitiba precisa saber: afinal o que mudou? Mudou o MST? Mudaram esses políticos?".

Fruto do mesmo jogo de representações, o vangloriado modelo sofre pesadas críticas dos candidatos opositores. Com a observação de que na "propaganda oficial, a cidade é filmada do alto, vista de longe", Maurício Requião, candidato do PMDB, percorre os bairros periféricos, entrevista populares e mostra que, contrariamente aos equipamentos oferecidos ao grande capital, neles as melhorias são pagas pelos moradores: "nós paguemo, e nós que fizemo!", afirma um morador. Mostra também a conotação eleitoreira de certas obras: "faz quatro anos que não mexiam no bairro, agora passaram esse asfaltinho", ao que acresce: "Cuidado que logo eles mandam a conta". Conclui o candidato, posicionando-se: "Os ricos me perdoem, mas vou ser o Prefeito dos pobres".

Em sua análise, reforçado pelo senador Roberto Requião, critica a exposição da cidade como um cenário, escondendo o debate, e ressalta os gastos

5 Nesse caso específico, os Deputados Estaduais Ângelo Vanhoni, do PT, e Caíto Quintana, do PMDB. do município com propaganda ("mais que São Paulo"): "Vaidade do Prefeito? Necessidade insana de se manter no poder? Propaganda que vende um produto com garantia vencida". Sua proposta é empregar esse recurso em obras sociais, até mesmo extinguindo a Secretaria de Comunicação Social: "Vamos acabar com a farra da propaganda".

Na seqüência da apresentação de suas propostas, o city marketing é com insistência o elemento introdutório: "Curitiba dos comerciais, dos cartões postais, do Prefeito, mostrada para turistas. Existe uma outra Curitiba, uma Curitiba de verdade, a Curitiba onde tudo falta. [...] Curitiba do desemprego, da violência. Nela também está sendo negado o direito à moradia, um sonho legítimo a cada família, o sonho da casa própria”. Com imagens da rede aberta de TV sobre violência urbana, afirma que a cidade requer mudanças na política, nas propostas e nas idéias.

De modo mais cauteloso, Ângelo Vanhoni, candidato do PT, adota a postura política de não desconstruir o modelo e os símbolos, nem desmontar as marcas anteriores, mas propõe avançar em busca da construção da cidadania, sem uma estratégia de confronto e de diferenciação profunda. Prega que "a cidade que quer ser gente continue se embelezando cada vez mais, mas que se preocupe em tornar mais bela e mais rica a vida de cada um dos curitibanos". Agrega ao seu desejo a reflexão de que "planejar uma cidade do ponto de vista urbano é muito importante; mas, mais importante que isso é planejar uma cidade do ponto de vista humano, oferecendo projetos para melhorar a vida de todas as pessoas". Essa visão é reforçada pelo apoio dado por Cristóvão Buarque, ex-Governador de Brasília. Segundo suas palavras, "o Brasil inteiro admira Curitiba pela capacidade de inovar em soluções urbanas. O Brasil quer admirar Curitiba por inovar no urbano e no social. Esta capacidade só se vê hoje na candidatura do Vanhoni".

Com texto poético sobre Curitiba, fala e percorre, com imagens, os locais tradicionais e os iconizados pelo modelo (Rua XV, Confeitaria Schaffer, Bar Stuart), confirmando, a seu modo, o consenso. Mas são tomadas de trabalhadores nas ruas que ilustram sua conclusão: "Curitiba é a cidade das pessoas que saem cedo de casa atrás de seus sonhos, andando pelas calçadas. Homens e mulheres que com o seu trabalho constroem a cidade. Curitiba é a cidade dessa gente que, apesar 
dos problemas, carrega um sorriso na cara. Essa gente que vai fazer de Curitiba uma grande cidade no $3^{\circ}$ milênio".

O mesmo tom de cautela caracteriza a crítica ao modelo feita por Márcia Requião, esposa de Maurício Requião. Sentada num parque da cidade, conta uma fábula: "Havia uma cidade onde as pessoas eram felizes. Chega um administrador, um mágico, que encanta a todos com a promessa de obras que colocariam a cidade no centro do mundo. $\mathrm{O}$ antigo administrador vai para uma ilha. Com o tempo, a população já não vive mais tão feliz. Falta emprego, falta segurança... [No mesmo tom, encerra com um alerta sobre a responsabilidade do voto]. Se erramos, pagamos um preço e por vezes um preço alto demais. Eu e Maurício estamos prontos a trabalhar pela nossa gente. Queremos ser os seus parceiros na reconstrução de uma cidade mais justa, menos desigual e mais solidária".

Forte Netto, candidato pelo PSDB, também critica o modelo por seus resultados segregadores e pelas diferentes leituras que gera: "Cada um fala de uma Curitiba. [...] Há muitas Curitibas. A diferença está em qual das Curitibas você vive, e são muitas. Como cidadão, eu não aceito o modelo administrativo que ajudou a criar tantas diferenças". Propõe-se a "transformar as diversas Curitibas em uma Curitiba só. Uma cidade igual para todos". Álvaro Dias, seu principal apoio, toca num dos elementos essenciais da modelização: "o sistema de transporte de Curitiba já foi modelo nacional, mas esgotou". Cita matéria da Globo comparando o setor em diversas capitais, reiterando essa conclusão; cita, ainda, dados da ONU, apontando que $30 \%$ das mortes dos jovens na cidade são devidas a causas violentas no trânsito. A solução é o metrô, aponta seu candidato, "nos moldes do Primeiro Mundo". Por trás da crítica, a manutenção das mesmas representações, com a reciclagem do modelo para lhe garantir atualidade.

Ainda no âmbito da crítica, Eduardo Requião, do PDT, propõe uma "cidade conhecida pela solidariedade, qualidade de vida, justiça social, não pelas belezas de concreto armado". Em seu discurso final, dedica o último programa a "esses amigos que sentem orgulho de sua cidade e gostariam de vê-la enaltecida como exemplo não apenas de obras arquitetônicas e urbanísticas, mas pelo tratamento carinhoso que concede a todos aqueles que nela se aconchegam". Tece uma analogia com a "mãe-cidade, aquela que trata todos os seus filhos com igual amor e respeito".

Embora as posições defendidas pelos candidatos demonstrem forte inclinação a manter ou rebater a imagem construída de cidade-modelo, é no discurso do governador Jaime Lerner que os elementos que materializam a modelização tornamse explícitos. Assumindo a personificação do projeto, sua própria paternidade, a condição de quem tem o poder de decidir por si o que é certo para toda a cidade, e colocando o seu candidato como participante desse processo, diz o governador Jaime Lerner (sob seu nome, na tela, a legenda "curitibano"):

"Boa noite, Curitiba. Peço sua licença por um minuto. No próximo dia $1^{\circ}$, vamos decidir como será a nossa vida nos próximos quatro anos. Quero, junto com cada um de vocês, pensar um pouco sobre este momento. Falo menos como governador e mais como curitibano que, com a confiança de todos vocês, teve a honra de ser Prefeito da cidade por três vezes. Pois bem, a hora é de responsabilidade. Com a lucidez histórica de nossa gente, Curitiba não vai renunciar às suas conquistas. Não vai abrir mão de seguir avançando e consolidando suas marcas registradas. A cidade ecológica. A cidade que tem melhor índice educacional do país. Que tem maior número de postos de saúde por habitante. Que é recordista no número de crianças em creches. Que possui o mais eficiente transporte coletivo do Brasil. Tudo isso feito para você. Claro, problemas sempre existem e vão sempre existir. Até porque quando um problema é resolvido, surgem outros no seu lugar, exigindo criatividade e ação. Por isso, eu que penso, planejo, vivo e respiro Curitiba há tantos anos, sei o que ainda precisa ser feito. E mais importante: sabemos todos, eu e você, que o Cássio é o Prefeito para continuar garantindo e ampliando as conquistas sociais que colocam o curitibano como centro de todas as coisas. O Cássio já provou que faz. Ele honrou seu voto. Não tenho dúvida. Ele e a equipe têm os melhores projetos para assegurar mais qualidade de vida para todos. Os outros, que não têm compromisso com a realidade, podem prometer o que quiserem. Podem tentar manipular as pessoas. Podem fazer demagogia. O Cássio não. Ele tem a competência, a seriedade e a serenidade que Curitiba exige. Não adianta a oposição atacálo para tirar o seu equilíbrio. Não tirarão. Porque seu equilíbrio é interior. Vem do fundo da alma. Vem da fé e da esperança de quem administra com 
a cabeça e o coração. Olha gente, amar é mudar a alma de casa. Eu mudei minha alma para a casa de cada um de vocês. Minhas filhas até dizem que são irmãs de Curitiba. E é verdade. Eu e a equipe, o Cássio sempre junto, dedicamos a mesma atenção que dedicamos aos nossos filhos. Eu me sinto um pouco parente de cada curitibano. Nós só fizemos o que Curitiba queria. [...] Nós crescemos juntos. Curitiba nos ensinou a gostar dela, respeitá-la. Por respeito a Curitiba vamos de novo. Vamos de Cássio".

Esse posicionamento, acionando o consenso, o orgulho cívico, o patriotismo, provocou a reação dos demais candidatos. Ângelo Vanhoni reitera, agora com menor parcimônia, seu reconhecimento aos louros do modelo: "Ao longo desses anos, Curitiba teve muitas conquistas. Tornou-se referência em vários aspectos para todas as cidades brasileiras. Mas Curitiba também mudou muito neste tempo. A cidade cresceu. Novos problemas surgiram. Os desafios para entrar neste novo milênio são imensos. No último programa eleitoral o governador Jaime Lerner ocupou espaço para falar como curitibano sobre o risco que a cidade corre de perder tudo aquilo que conquistou. Pois bem, hoje eu quero pedir licença para falar com nosso governador. Quero dizer para você, Jaime, como curitibano, que não há o que temer. Assim como você, existem muitas pessoas que também se preocupam e amam nossa cidade: engenheiros, arquitetos, trabalhadores, donas de casa, empresários. Gente que quer contribuir para o debate sobre o futuro que é de todos nós. Você me conhece Jaime. Neste espaço eleitoral eu tenho trazido propostas e idéias, que, tenho certeza, vão contribuir para tornar Curitiba ainda melhor. Nós queremos uma cidade que não seja apenas referência como planejamento urbano. Nós queremos uma cidade que seja modelo também pela transparência administrativa. Pelo cuidado com as crianças e os idosos. Pela valorização dos professores e da educação. E pela participação das pessoas com suas idéias e seus sonhos. Vamos encontrar o equilíbrio entre crescimento e a preservação de nossos mananciais. Vamos encontrar novas maneiras de tornar nosso transporte coletivo ainda mais eficiente. Vamos trazer idéias e propostas que já foram consagradas em outras cidades brasileiras como a Bolsa-Escola e o Banco do Povo, que vão trazer enormes benefícios para nossas mães e crianças. Idéias que Curitiba e você certamente vão aplaudir. Para discutir todas estas propostas eu quero fazer um convite. Um convite para você participar ativamente deste grande debate, que vai acontecer agora no segundo turno. Nós da oposição estamos prontos. Nosso coração está aberto para isso e eu tenho certeza que o seu, Jaime, e os de todos os curitibanos, que também amam esta cidade, também vão estar. Porque, afinal, é sempre bom lembrar o poeta: na vida tudo vale a pena quando a alma não é pequena".

Na mesma linha, rebate Forte Netto: "Vimos o governador no programa do Prefeito dizendo que ele se sente como pai de Curitiba. Uma cidade não tem pai. Ela não pode ser de um único dono. Ela é dos que aqui nasceram, dos que aqui chegaram e dos que ainda estão por vir. Ela é de cada um de nós, seus cidadãos, que a construímos e que a amamos de verdade. Cidadãos que têm a capacidade e o direito de fazer suas próprias escolhas sem medo. O filósofo já dizia: A cidade são as pessoas".

Maurício Requião toca mais diretamente no "cuidar bem de Curitiba", afirmando que isso "[...] é dar a nossas crianças uma escola de qualidade que prepare para a vida. É garantir remédio, atendimento, exames, tratamento e hospital para quem precisa. Vou cuidar bem de Curitiba criando empregos porque não existe nada mais cruel que negar salário e trabalho às pessoas. Cuidar bem de Curitiba é asfaltar as ruas, fazer calçadas, sanear os bairros tornando bonito e agradável o lugar onde moramos. Cuidar bem de Curitiba é aplicar bem, com responsabilidade e eficiência, cada centavo do dinheiro público. Cuidar bem de Curitiba é diminuir os impostos: o IPTU, o ISS Não sacrificar a população com esta voracidade de arrecadar. Cuidar bem de Curitiba é pôr fim nesses projetos mirabolantes e caros que enriquecem empreiteiros e endividam a população. Quem paga tudo isso? Cuidar bem de Curitiba é fazer bem feito tudo aquilo que a cidade quer e precisa. Eu vou cuidar bem de Curitiba. Vou cuidar da cidade com o mesmo zelo, o mesmo carinho e a mesma responsabilidade que cuido de minha própria família".

\section{II.2 INTERNACIONALIDADE E SUSTENTABI- LIDADE}

Para garantir o consenso do curitibano em relação ao projeto, as articulações lógicas que sustentam o discurso oficial do modelo seguem o mesmo padrão de modelização adotado por tantas 
cidades, que se apresentam como aquelas que proporcionam aspectos que outras cidades gostariam de imitar.

Nesse ponto, sua projeção internacional contribui bastante para facilitar a aceitação do modelo por parte dos cidadãos. A opinião do estrangeiro chega a ser transformada em medida da qualidade dos projetos, proporcionando "mais uma leitura positiva da modernização e, ademais, por um juiz supostamente imparcial e qualificado" (SÁNCHEZ \& MOURA, 1999, p. 98-99) - especialmente se cidades estrangeiras passam a importar sua experiência, a comprar seu know-how. Nem reforçam seu poder de convicção no prestígio dos sujeitos e instituições de onde emanam e circulam enquanto fluxos, ou seja, nas premiações ou simples menções ao modelo da cidade expressos pelo Banco Mundial, ONU, BID, e pelas grandes mídias internacionais, cujo peso político contribui na consolidação do poder local. Isso mostra que "a construção de uma cidade-modelo é, por si mesma, uma estratégia de internacionalidade" (BENACH \& SÁNCHEZ, 1999, p. 40).

Essa prática, perfeitamente pensada, é abordada num dos programas de Cássio Taniguchi: "O nome Curitiba corre o mundo, dizendo criatividade, planejamento. Desperta o encanto do estrangeiro, fica na memória de técnicos do mundo inteiro". Com essa introdução, sucedem no roteiro Domenico De Masi, entrevistado por Marília Gabriela, elogiando nominalmente Cássio Taniguchi e o governador do Paraná; o Prefeito de Los Angeles, visitando o sistema de transportes e dizendo que "a mágica que vimos em Curitiba é incrível", e uma sequiência de imagens rápidas da mídia internacional referindo-se a Curitiba: cidade exemplo de administração e planejamento, do Daily News; documentário "Curitiba, um modelo de cidade", de uma TV francesa; política urbana garantindo o meio ambiente, da $T V N H K$ (Japão); matéria da World TV, Canadá, com texto no qual claramente se ouve a expressão "international superstar", tratando das soluções aos problemas urbanos; e de uma emissora de rádio e TV belga, enaltecendo a administração igualitária, com chance para todos.

Mas não basta a mídia. Seu discurso eleitoral mostra que também nas "publicações mais respeitadas" o modelo é apresentado, como na National Geographic: "Curitiba, modelo em planejamento urbano"; Time: "soluções criativas para problemas sociais"; The Economist: "Curitiba foge dos en- garrafamentos e da poluição com sistema de transporte eficiente"; Scientific American: "a cidade desafia convenções e melhora qualidade de vida"; Los Angeles Times: "a cidade mais inovadora do mundo"; Yomiuri Shimbum (Tokyo): "Curitiba é exemplo na preservação do meio ambiente"; Air France Magazine: "Cássio é continuidade na transformação que é referência no respeito ao cidadão".

Ainda associada à noção de cidade-modelo, encontra-se a noção de "cidade sustentável", carregada de uma subjetividade que aciona diversas representações para a gestão da cidade. Dentre elas, a que a associa "a estratégias de implementação da metáfora cidade-empresa que projetam na 'cidade-sustentável' alguns dos supostos atributos de atratividade de investimentos no contexto da competição global" (ACSELRAD, 1999, p. 81). Ou seja, requalificar o ambiente urbano para realçar a atratividade, inspirar orgulho nos moradores e, principalmente, ganhar confiança dos potenciais investidores.

Essa noção, amplamente usada nas administrações anteriores, não foi o foco dessa campanha; mesmo assim, em seu discurso, o governador Jaime Lerner evoca a "capital ecológica". O candidato que apóia apenas tangencia o tema ao apresentar o planejamento urbano como minimizador da degradação ambiental. Para Cássio Taniguchi, o desafio das cidades é "enfrentar o crescimento sem perder a qualidade de vida, que faz da nossa cidade um modelo para o mundo". Refere-se a que essa resposta dada por Curitiba deve-se ao seu passado e volta-se ao futuro: "o que fizemos com planejamento e visão estratégica é que permitiu crescer com qualidade, diferente das demais; para o futuro, [devemos] ampliar as conquistas com equilíbrio, bom senso, criatividade, conhecimento técnico, mas muito, muito conhecimento técnico".

Nesse padrão discursivo, a racionalidade técnica adquire um peso que dispensa qualquer discussão. Verifica-se uma nítida despolitização da questão ambiental, uma recusa ao reconhecimento de conflitos entre meio ambiente e economia, e, principalmente, de que o ambiente da cidade não se encerra em suas fronteiras político-administrativas.

No tratamento dos demais candidatos, a noção foi alvo de crítica. Com a imagem chocante de um homem que, tomando água com canudinho, vira um esqueleto, Maurício Requião refere-se ao 
marketing ambiental das administrações anteriores: "A propaganda do governo diz que Curitiba é a capital ecológica e todos os nossos rios estão mortos. Iniciar a recuperação de nossos rios: este é o compromisso de Maurício Requião".

\section{3 GENTRIFICAÇÃO E COMPETITIVIDADE}

A materialização da ideologia hegemônica exige a reestruturação urbana, pois o poder se consolida na arquitetura e no urbanismo. Apoiados no city marketing, que redireciona as práticas recorrentes da vida cotidiana, projetos "modernizantes" 6 tentam transformar a cidade para torná-la competitiva, revelando uma intencionalidade externa ao lugar. Esses projetos passam a cor-porificar as políticas urbanas recentes, tornando-se sua própria síntese. Políticas urbanas que, fundadas na "gentrificação"7 dos espaços da cidade, passam a exercer novas formas de controle social.

Assim, a gentrificação urbana abre possibilidades a todos os tipos de investimentos imobiliários, muitas vezes resultando na reprodução em série de parques, na elitização de bairros, na construção de shopping centres, centros de entretenimento, centros culturais. Esses objetos urbanos passam a se constituir em marcas da modernidade e, portanto, em cartões de visita na política da atratividade, garantindo maior mobilidade ao capital multinacional. Elevam o valor das propriedades, da base tributária e da circulação local da renda. Inventam, até mesmo, o consumo da tradição, ao serem construídos monumentos, parques, memoriais e praças ao estrangeiro, a grupos étnicos ${ }^{8}$.

6 Não só projetos, mas toda uma série de normas e procedimentos que criam as bases para a entrada do capital global, a exemplo dos dispositivos introduzidos pela atual Lei de uso do solo (cf. MOURA, 2000).

7 Expressão "cujo caráter de classe o original inglês (gentry) deixa tão vexatoriamente a descoberto" (ARANTES, 2000, p. 31). No sentido de origem, significa a invasão e reconquista, inerentes ao retorno das camadas afluentes ao coração das cidades. Empregado eufemisticamente como revitalização, reciclagem, requalificação, escamoteia seu real significado. Assim, gentrification "é uma resposta específica da máquina urbana de crescimento a uma conjuntura histórica marcada pela desindustrialização e conseqüente desivestimento de áreas urbanas significativas, a terceirização crescente das cidades, a precarização da força de trabalho remanescente e sobretudo a presença desestabilizadora de uma underclass fora do mercado" (ibidem).

8 Nos anos 90, a política cultural oficial em Curitiba foi exemplar dessa prática, pois "recompõe as várias culturas que participaram do movimento de colonização da região,
Associados, urbanismo e cultura passam a inserir no conteúdo da cidade-mercadoria a "comoditização" urbana. Nesse contexto, por se apoiar em movimentos efêmeros, tal associação surte efeitos paliativos, que se tornam rapidamente obsoletos. A história também é reinventada e/ou editada, sendo possível ignorar aspectos considerados pelos grupos dirigentes como "memórias não memoráveis": o negro, o índio, ou grupos não representativos do primeiro mundo. Ao mesmo tempo, é possível espetacularizar uma falsa história (IRAZÁBAL, 2000), transformando o passado e a cidade numa commoditty para o consumo de massa e como potencial para investimentos turísticos. Promove-se "a 'venda da etnicidade' na falta de mercado para sua força de trabalho" (ARANTES, 2000, p. 24).

A intervenção pública não é minimizada, mas submetida aos interesses do setor privado, ou "ao interesse privado dos capitalistas" (VAINER, 2000). Um convívio "promíscuo que põe lado a lado a cultura do dissenso e os donos do dinheiro e do poder" (ARANTES, 2000, p. 12).

Passa-se a "fazer a cidade", e, nesse processo, o arquiteto-urbanista, urban imagineers, torna-se o intermediário cultural e planejador-empreendedor, o criador de "lugares" na cidade, fornecedor de bens e serviços simbólicos e principal agente da gentrification. Lugares que, tidos como pontos identitários das comunidades, nada mais são que meras reproduções de formas e conteúdos da globalização - verdadeiras "paisagens do poder"" Na produção material do espaço urbano, percebese o retorno ao urbanismo monumentalista,

através de memoriais étnicos na arquitetura urbana associados a novos parques como o Tingüi, dos ucranianos, o 'Bosque Alemão', ou o 'Bosque do Papa', dos poloneses. Esses espaços de celebração das etnias e da natureza exaltam, ao mesmo tempo, o próprio projeto de cidade, o modelo. Fabrica-se uma identidade fake, portanto sem resistência. Desencadeiase uma lógica de evocação que mais funciona como uma antimemória coletiva que esconde as marcas do tempo, reprime as metamorfoses do espaço e acarreta uma redução ao idêntico. A política cultural é, de fato, o álibi com o qual se fabrica o espelho que reflete seu próprio poder" (SÁNCHEZ \& MOURA, 1999, p. 108).

9 Essa expressão é tirada de Arantes (2000), que por sua vez tirou-a de Zukin (1991; 1992), respectivamente: Landscape of Power. From Detroit to Disney World, e The city as a landscape of power. Nessas obras, a autora demonstra que as mesmas instituições financeiras se encontram formatando as áreas centrais de muitas das cidades globais. 
"produzindo ao final do século XX os novos arcos do triunfo do capital transnacionalizado" (VAINER, 2000, p. 94).

O principal exemplo da incorporação dessa tendência no discurso eleitoral encontra-se na propostas de renovação - a face exposta da gentrificação - do bairro Rebouças. Apresentada pelo candidato Cássio Taniguchi, a proposta é introduzida com realce à busca da identidade, à preservação da memória, à parceria prevista para seu detalhamento, numa verdadeira cumplicidade no processo criativo: "A história de Curitiba é a história de seus bairros. A estação ferroviária lembra antigas viagens, as primeiras construções industriais de Curitiba; essas construções do passado sugerem que essa área nobre da cidade encontre uma nova vocação". Após essa fala, a proposta de transformar o Rebouças no bairro jovem de Curitiba é apresentada numa sequiência de desenhos padrão história em quadrinhos, e num linguajar apropriado das gírias da juventude local: "fazer do Rebouças uma porta para o futuro; a juventude, a galera vai decidir qual será o lance do novo Rebouças [...] [nesse ponto, encerra a narração em off e o próprio Cássio pergunta:] Que tal um local de trabalho, diversão e cultura dia e noite? Velhos barracões de cara nova pro agito, bandas de garagem, shows e festivais de música; estúdios de cinema, produção e festivais; local irado para o pessoal que quer ficar sempre com o corpo sarado, academias, games, livros, CDs, internet, centros de línguas, capacitação pra profissões ligadas à informática? Tem lugar para tudo. [...] A revitalização deve priorizar a inquietude, a vontade dos jovens. Nossa equipe já tem mais de 30 anos. Participe, bote a imaginação pra funcionar. Você deve decidir inclusive o nome do projeto".

Nesse ponto, a informática emerge como o elo moderno do diálogo com a juventude: qualquer sugestão pode ser enviada por correio eletrônico. Em continuidade, a renovação desse bairro associase a outro projeto polêmico apresentado na campanha: "Faça bater um novo coração no velho Rebouças. O futuro já está mais perto dele: é lá que o Cássio vai fazer a estação central do metrô".

Mais um exemplo perfeito, porém menos detalhado, apresentado pelo mesmo candidato é o de desativação da Penitenciária do Ahú, com a restauração do prédio e construção de praça pública. Localizada numa área nobre da cidade, a proposta da mudança de uso desse espaço significa desencadear um novo processo de gentrificação, de "limpeza" da área. Decerto, beneficiará os mesmos segmentos locais, desde há muito beneficiados, e abrirá possibilidades à inserção de novos capitais internacionais envolvidos no mercado imobiliário, comercial, e - por que não? - cultural. A mesma intervenção é proposta por Jamil Nakad, que indica sua transformação em Presídio Cultural - afinal (e lembrem-se de seu tom jocoso), "lugar de marginal é no Presídio Agrícola, trabalhando e pagando a pena".

Propostas adicionais ou apenas lembranças de realizações completam o seu quadro revitalizador, como o Programa Memória Curitibana, que prevê a restauração de prédios históricos degradados no centro da cidade, ou mesmo as obras em andamento (escolas, postos de saúde, esgotos, avenidas, terminais, estações-tubo etc.) - "bairros virando verdadeiras cidades". Nas entrelinhas, esse quadro mostra também a adaptação da cidade ao meio informacional: o programa Rede do Conhecimento, voltado a ampliar horizontes para aluno, professor e comunidade, prevê a instalação de redes de computadores nas escolas e Faróis do Saber, ligadas a centros de tecnologia, universidade etc., constituindo a Rede de Aprendizagem, com a qual toda a comunidade terá acesso à internet, e, portanto, a um franco "diálogo" com a administração, pois "pela rede você vai estar em linha direta com o Prefeito". Num link com a cultura, propõe o Liceu da Informática, numa reciclagem do prédio central da Capela do Colégio Santa Maria, que fará parte do complexo Teatro Guaíra. Nesse ramo da cultura, com desenhos ilustrativos, propõe a criação de novos espaços culturais, culminando com um teatro para apresentações de grupos experimentais. Dessa forma, materializa a associação urbanismo-cultura e, em mais um aspecto, adapta a cidade ao diálogo global.

"E assim por diante, vão as grandes corporações multinacionais tratando de nos persuadir de que os verdadeiros protagonistas da cena mundial são - quem diria! - as cidades, ou melhor, cidades cuja configuração seja propícia à valorização patrimonial que mais interessa a tais firmas no presente estágio de transnacionalização produtiva. Rentabilidade e patrimônio arquitetônico-cultural se dão as mãos, nesse processo de revalorização urbana sempre, evidentemente, em nome de um alegado civismo (como contestar?). E para entrar nesse universo dos negócios, a senha mais prestigiosa a que ponto chegamos! (de sofisticação?) - é a 
cultura, essa nova grife do mundo fashion, da sociedade afluente dos altos serviços a que todos aspiram" (ARANTES, 2000, p. 30-31).

Mas está na proposta do metrô o elemento requalificador mais polêmico da campanha. Com a intenção de reciclar o tão premiado modelo em transporte coletivo, com novos modais e trajetos, a atual administração vem propondo a renovação de uso de um corredor hoje percorrido pela BR116, que será desviada após a conclusão da via de contorno. Com seqüência de imagens que rememoram a história do sistema em Curitiba, o candidato faz seu apelo: "Curitiba não quer que essa evolução histórica seja interrompida". Nesse sistema premiado, mostra que o metrô é nova etapa, novo avanço, com visão metropolitana, com aumento da capacidade do sistema (3 linhas iniciais, 20 estações, conforto, paisagismo, igual a qualquer metrô do mundo). Conclui afirmando: "Curitiba, história de técnica e planejamento a serviço da população". Em outra seqüência, retoma: "Metrô de Curitiba. O próximo passo para um sistema que é modelo no Brasil e no mundo. Antes que o problema apareça a gente apresenta uma alternativa. [...] O traçado do novo metrô é coerente à visão estratégica que temos de Curitiba e com a atitude da qual não abrimos mão: manter a função social do transporte coletivo de Curitiba. Por isso ele vai atender à área da cidade que mais cresce. [...] Seu objetivo é tirar de circulação os ônibus metropolitanos do centro da cidade" (essa tomada encerra-se com imagens de pessoas nas ruas, algumas em terminais, dizendo que confiam em Cássio e que ele entende de transporte urbano).

Polêmico pela escolha do percurso, esse projeto introduz um modal elevado e recria a paisagem de uma área, já integrada num dos eixos de verticalização dispostos pela nova Lei de uso do solo. Longe de ser aceito pelo capital imobiliário local (até porque não tem estoques especulativos na região), esse eixo foi tido como uma ameaça, pois, com a alteração do coeficiente construtivo, apenas grandes capitais externos terão a possibilidade de adquirir imóveis que permitam a execução dos edifícios, respeitadas todas as exigências de recuo. Capitais, por sinal, já participantes em um fluxo de inversões que transcende Curitiba, integrandoa ao seu conjunto metropolitano e aos eixos de ligação com o Porto de Paranaguá e com o norte e o sul do país. Sua introdução local se deu com amplos subsídios governamentais, dentro de um processo de refuncionalização de municípios periféricos ao pólo, para que fossem criadas as condições necessárias à inserção da metrópole no processo de reestruturação da economia global. Tal prática, recorrente nas gestões mais recentes de Curitiba, trouxe o fenômeno metropolitano ao discurso oficial, tornando a integração regional um dos objetivos da última administração. Objetivo que foi ignorado por completo não só no discurso eleitoral do candidato à reeleição - não estando explícito nem mesmo na justificativa locacional do projeto do metrô - como no dos demais candidatos, evidenciando que são tidas como mais importantes as relações verticais entre o lugar e o mundo, que suas relações horizontais com a vizinhança (SANTOS, 2000).

Forte Netto não descarta a possibilidade do metrô, mas defende que seja no centro: "O metrô deve passar onde as pessoas moram, estudam, trabalham e se divertem". Entrevistas com populares confirmam a escolha central e o candidato afirma que é preciso ter "bom senso, como no primeiro mundo. Lá o metrô passa por onde as pessoas circulam". Propõe que circule nas atuais canaletas das vias estruturais da cidade: av. Paraná, av. João Gualberto, av. Sete de Setembro e av. República Argentina, na primeira fase. Demonstra sua proposta no mapa de densidade populacional, no qual o adensamento maior é visível nos eixos estruturais, e agrega que o metrô "deve ter origem num projeto bem feito, com consenso, com visão de futuro"; será elevado, sem investimento público, mas com a iniciativa privada responsabilizandose em construir e operar (como o transporte coletivo), com supervisão da Prefeitura; a sociedade pode contribuir para o aperfeiçoamento da idéia. Também a sociedade deve participar na discussão das obras de engenharia para o trânsito, que busquem evitar congestionamentos. Já antevê vias elevadas sobre os canteiros centrais nas avenidas Visconde de Guarapuava e Silva Jardim, duplicando a capacidade de funcionamento e respeitando a mão única de direção: "Proposta baseada no bomgosto e beleza, que sempre caracterizaram minhas obras nos 40 anos de vida profissional, e no bomsenso. Como já declarei, será amplamente discutida com a população. É técnica e ambientalmente correta". Segundo informa, o projeto proposto é cinco vezes mais barato que o subterrâneo.

O candidato Ângelo Vanhoni, apoiado em desenhos, também advoga o metrô no centro, mas "embaixo da terra", ligando os bairros do Pinheirinho ao Santa Cândida. Com imagens do atual 
sistema, discute sua saturação e a necessidade de ser modernizado e aperfeiçoado. Quanto ao novo corredor proposto pelo adversário, admite que a BR-116 divide a cidade como uma verdadeira muralha. Mas a solução seria urbanizar e integrar com biarticulados, num projeto que reúna soluções de transporte de massa, planejamento urbano e meio ambiente, preservando os mananciais da região.

Maurício Requião posiciona-se contrário à centralidade que o metrô adquiriu no debate eleitoral: "Falam em metrô. Me desculpem, eu quero ser Prefeito para diminuir as desigualdades, para promover justiça, dar força aos mais fracos. Garantir o valor e a dignidade do trabalho. Valorizar os idosos. Dar futuro às crianças. Por isso vou construir creches, casas populares, melhorar a educação e a saúde. Combater com energia a violência e fazer políticas para gerar emprego". (Diante da polêmica do tema, passa a empregar o mote "Enquanto falam em metrô eu vou..." e lista inúmeras ações na área social.)

De modo geral, a modernização da cidade torna-se incontestável. Mas, na atuação proposta pelo candidato à reeleição, aproximar a cidade dos requisitos globais é o que mais interessa. Com isso, talvez efetive sua afirmação de que Curitiba é "a melhor cidade do Brasil para se fazer negócios". Tal escolha é amplamente aceita pela população sob o impacto da estagnação econômica, e sob o efeito de uma campanha de convencimento que lhe atribui uma sensação coletiva de crise, levandoa a abraçar consensualmente qualquer intervenção ilustrada pela perspectiva de oferta de emprego.

Assim, torna-se legítima a aparente possibilidade de sucesso de uma ação pautada no voluntarismo e que se resume em incrementar a atratividade urbana, como se os demais fatores fossem naturalmente carreados por ela. A característica central desse novo empresariamento está na noção de parceria "público-privado". Uma parceria empresarial, porque tem sua execução e concepção sujeitas a dificuldades e riscos inerentes aos investimentos especulativos, que se contrapõem àqueles organizados e planejados racionalmente. Em muitos casos, esse risco onera o poder público, enquanto a iniciativa privada apenas assume os benefícios (HARVEY, 1996).

Dessa forma, a reestruturação urbana consolida relações de poder ao adaptar as estruturas urbanas às exigências do capital em trânsito; as intervenções são naturalizadas como imprescin- díveis e aceitas como uma opção inquestionável. Santos discorre sobre os efeitos perversos dessa naturalização: "O grande risco desse enfoque das coisas é que a gente pode descambar para a estética, não é isso? E para a cosmética urbana, que é a grande moda atual. E para o divertimento das pessoas. E, com isso, se desvia também a direção política. Você não enfrenta os problemas: oferece cristalizados os novos espaços. E aî também ajuda os escritórios. Aos grandes, você dá as grandes obras, e aos pequenos e médios você dá as renovações locais: 80,100 pracinhas. E diz que está planejando a cidade toda para os pobres e para o futuro" (SANTOS, 2001, p. 4-5).

Essa mesma sistemática em exercício na gestão pública das administrações engajadas nos processos de reestruturação produtiva permeia o discurso dos candidatos, ao se referirem à necessidade de tornar a cidade competitiva para ampliar as possibilidades de oferta de emprego, ou para modernizála e aperfeiçoar a qualidade de vida urbana.

Cássio Taniguchi, dentre as propostas que associam renovação urbana e emprego, inclui uma que adentra diretamente o imaginário da população: o Linhão do Emprego, que significa a reciclagem de extensas áreas abrindo alternativas para instalações econômicas. Na proposta, o Linhão de Cima, já que vai se situar na porção norte da cidade, cortará uma área de torres de alta tensão: "pela avenida passa uma Curitiba que vai desenvol-ver mais ainda”. O Linhão de Cima (FazendinhaAtuba) estará associado à Linha Verde (desde o Parque São Cristóvão até o Maracanã), integrandose ao metrô, ao anel viário, articulando parques, turismo e lazer, "com infra-estrutura para receber turistas", culminando com a criação do parque do Atuba, voltado à prática de esportes radicais.

Além da adequação para a instalação econômica, a renovação urbana também se faz justificar na proteção à violência. Recriar espaços é garantir a convivência pacífica, sob controle de seguranças. Arantes, mais uma vez, refere-se a Zukin e cita a "estetização do medo", induzida pela atual fase da gentrificação que, ao transformar os espaços públicos em edificações cercadas e vigiadas, apresentase na arena urbana, como uma "revanche contra trabalhadores precarizados, imigrantes, sem-teto etc., enfim, todo o tipo de classe perigosa que possa ameaçar o sono dos vencedores de ontem" (ARANTES, 2000, p. 37). Assim, a gentrificação restabelece a ordem, e, portanto, a "civilidade". 
No caso de Curitiba, a questão da violência é a grande ameaça ao modelo e à sua perspectiva de competitividade. Recente pesquisa realizada em Curitiba, com jovens nascidos sob a égide do modelo, aponta que a maior preocupação deles é a violência urbana, seja por parte de grupos organizados, seja mesmo por parte da polícia (SALLAS, 1999). Esse tema é captado por todos os candidatos, que colocam a segurança dentre as políticas sociais prioritárias (anexo 3). No entanto, é Maurício Requião que faz a associação direta com a arquitetura da proteção: "Mostrei que a violência e o desemprego podem ser enfrentados. Os condomínios de segurança levarão uma nova polícia para perto das pessoas" - idéia que, na sua raiz, acaba por circunscrever práticas segregadoras.

Neste ponto, cabe alertar que a questão da violência também serve de máscara a uma importante vertente do pensamento único que, segundo Wacquant, inscreve-se em uma constelação discursiva de termos e teses vindos dos Estados Unidos sobre o crime, a violência, a justiça, a desigualdade e a responsabilidade - do indivíduo, da "comunidade", da coletividade nacional. Termos e teses que pouco a pouco se insinuaram no debate público, dissimulando, com a banalização de lugarescomuns, os riscos quanto à redefinição do papel do Estado, ausentando-se da arena econômica e social, e ampliando sua intervenção penal. Para o Autor, a penalidade neoliberal apresenta o paradoxo de pretender "remediar com um 'mais Estado' policial e penitenciário o 'menos Estado' econômico e social que é a própria causa da escalada generalizada da insegurança objetiva e subjetiva em todos os países" (WACQUANT, 2001a, p. 7), salientando que ela é "mais sedutora e mais funesta quando aplicada em países ao mesmo tempo atingidos por fortes desigualdades de condições e de oportunidades de vida e desprovidos de tradição democrática e de instituições capazes de amortecer os choques causados pela mutação do trabalho e do indivíduo no limiar do novo século" (ibidem).

"Isso quer dizer que a alternativa entre o tratamento social da miséria e de seus correlatos ancorados numa visão de longo prazo guiada pelos valores de justiça social e solidariedade - e seu tratamento penal - que visa às parcelas mais refratárias do subproletariado e se concentra no curto prazo dos ciclos eleitorais e dos pânicos orquestrados por uma máquina midiática fora de controle, diante da qual a Europa se vê atualmente na esteira dos Estados Unidos, coloca-se em termos particularmente cruciais nos países recentemente industrializados da América do Sul, tais como o Brasil e seus principais vizinhos, Argentina, Chile, Paraguai e Peru" (idem, p. 11) ${ }^{10}$.

\section{GOVERNABILIDADE: PARTICIPAÇÃO OU CONSENSO?}

O discurso oficial da gestão em Curitiba, fortemente associado ao que veicula a idéia de planejamento estratégico, tem inegável poder de convencimento, mas não incorpora a fragmentação e a desigualdade acentuadas pelo processo de globalização. Seletivo na escolha dos interlocutores e restritivo na definição de prioridades, esse modo de planejar instaura um processo fundamentalmente desmobilizador das forças populares e do exercício da cidadania, negando a cidade como espaço de construção política e social, reduzindo-a a locus do investimento - condição que norteia o modelo de governança ${ }^{11}$ local, definindo as relações público/privado, a lógica das políticas públicas implementadas e a existência, ou não, de instâncias de participação popular na definição das políticas da cidade.

Nesse modo verticalizado de planejamento e gestão, há escassos canais democráticos de participação, a despeito da ampla participação preconizada pelo modelo, que, nesse caso, parece se constituir mais em uma adesão social ao projeto hegemônico - acrítica e reverenciadora - do que propriamente em uma prática de cidadania. A essa adesão Vainer (2000) chama de um estimulado "patriotismo urbano" e o considera um poderoso componente autoritário desse modelo de cidade.

Em Curitiba, as instâncias de participação nos projetos urbanos têm um conteúdo tenuemente consultivo e claramente legitimador das políticas oficiais. O influente envolvimento em esferas decisórias fica restrito aos atores partícipes das coalizões dominantes ligadas aos grandes interesses localizados (OLIVEIRA, 1995).

Manifestações espontâneas de crítica ou rejei-

10 Sobre esse tema, o próprio autor recomenda a leitura de Wacquant (2001a; 2001b).

11 Entende-se por "governança" o modus operandi das políticas governamentais, conforme conceito de Melo (1995).Adotase esse conceito considerando as lutas políticas travadas entre os diversos atores sociais na definição das políticas públicas locais. 
ção ao processo são compreendidas e veiculadas, pela mesma retórica oficial, como "perturbação da ordem", com ameaça à governabilidade. Técnicas de comunicação são empregadas para conter o antagonismo: campanhas publicitárias de amplo alcance, usando os diversos veículos midiáticos, passam a enaltecer as novas obras da cidade conferindo-lhes o status de marca registrada - e a confirmar o papel exercido e delegado ao poder público numa ação "concertada" com os demais agentes intervenientes. Esse processo torna nítida a diferença entre participar e ser participado, ou chamado para referendar.

Uma análise dos elementos que propiciaram a produção dessas intervenções urbanas que caracterizam o "urbanismo curitibano" observa que o "efeito de estetização e naturalização das práticas de poder, cujo alvo é o comportamento dos indivíduos, parece ser o fator explicativo do êxito do urbanismo em Curitiba" (SOUZA, 1999, p. 300). Essa constatação local é seguramente generalizável, pois a manipulação de linguagens simbólicas "o 'visual' de uma cidade, bem como a maneira pela qual ela se deixa por assim dizer manusear, seu aspecto 'tátil', podemos acrescentar, refletem decisões sobre o que, e quem, pode estar visível ou não, decisões em suma sobre ordem e desordem, o que acarreta algo como uma estetização do poder, da qual o desenho arquitetônico é um dos instrumentos mais aparatosos" (ARANTES, 2000, p. 33).

$\mathrm{Na}$ análise de Souza, dois elementos constituintes da explicação oficial do sucesso do planejamento urbano em Curitiba merecem ser ressaltados. Elementos imprescindíveis não somente para a compreensão do estilo hegemônico de governança local, mas determinantes na formulação do discurso dos candidatos postulantes à Prefeitura.

$\mathrm{O}$ primeiro diz respeito à população. Mediado pela interação criador-criatura, a ordenação do espaço da cidade constrói o "curitibano" residente na cidade protagonista. Citadino ${ }^{12}$ naturalmente pacífico e exigente, instituído de aguçado senso estético e um inabalável amor cívico pela cidade, tem, no discurso dominante, seu papel político

\footnotetext{
12 Utiliza-se a terminologia "citadino", conforme Vainer, com o intuito de estabelecer uma distinção que reflete a despolitização do significado de cidadania. "Enquanto estes (os cidadãos) se dividiriam quanto a visões ideológicas, projetos de sociedade e prioridades nacionais, os citadinos estariam acima (ou além) destas pugnas” (VAINER, 2000, p. 96).
}

reduzido a objeto e objetivo das intervenções urbanas. Esse "curitibano" objeto, associado à imagem da cidade sujeito, é lembrado no discurso do governador Jaime Lerner, valendo acentuar: "Tudo que é feito aqui tem um toque especial da nossa gente. [...] Curitibano tem bom gosto elevado e não vai aceitar. [...] O curitibano ama Curitiba porque Curitiba sabe, como nenhuma outra cidade, amar o cidadão.[...] Nós só fizemos o que Curitiba queria".

A composição étnica da população de Curitiba, resultante da imigração européia e japonesa, "supostamente mais civilizada e trabalhadora do que outras etnias que teriam povoado cidades de menos sorte" (SOUZA, 1999, p.136), impõe-se no discurso como um fator que naturalmente a qualifica para viver numa sociedade racional sob a égide do planejamento técnico. Contudo, a "produção" do curitibano, ao propiciar a adesão ao projeto dos segmentos médios da sociedade, constitui-se em garantia da governabilidade dos grupos de poder hegemônicos.

A construção de um passado e a elaboração de saberes sobre os grupos étnicos idealizados como fundadores da cidade, sobre seus papéis na história e seus lugares devem ser vistas como momento fundamental da prática administrativa de ordenação racional do espaço urbano a serviço do tempo e da normalização dos sujeitos. Esses procedimentos encontram-se inseridos no jogo de formação de uma governamentalidade sobre a população urbana (idem, p. 139).

Para a população ideal, o governante ideal esse é o segundo elemento de análise. O festejado êxito do planejamento curitibano consagrou a imagem de inquestionável e apolítica competência técnica do grupo de arquitetos-urbanistas responsável pelo planejamento e pela reforma urbana de Curitiba. Essa condição vem garantindo a esse grupo seguidas vitórias eleitorais, principalmente em instâncias administrativas.

Essa importância dada à personificação do modelo na figura de seu "idealizador", o técnico competente, está presente tanto na fala do governador quanto na resposta da oposição. No discurso do governador Jaime Lerner, o "profissional", mais que o "político", é quem decide. A imagem é composta com extremo cuidado: Cássio, em todos os programas, aparece junto a uma prancheta, sentado, compenetrado, criando. E essa criação é mostrada como unanimemente aceita, com um 
elevado "patriotismo cívico", por uma cidade que também é personificada: (voz em off) "O Curitibano ama Curitiba, [...] tem orgulho de ser curitibano, [...] porque Curitiba sabe, como nenhu-ma outra cidade, amar o cidadão". Nesse plano, sucedem-se imagens com referência às campanhas vencedoras do "coração curitibano" (mote de eleições anteriores) e cenas da equipe de Cássio planejando em volta de uma mesa grande com mapas, desenhos, material de arquitetura. $\mathrm{O}$ governador Jaime Lerner está lá, de costas para a câmara. Técnicos sérios, conversam agradavelmente sob uma luz difusa e também agradável.

Para administrar a competitiva cidade de Curitiba - unanimidade nacional e internacional no quesito qualidade de vida -, o candidato à reeleição constrói sua imagem no modelo de governança recorrente em outras campanhas eleitorais de seu grupo político. Apresenta-se como um técnico urbanista competente, "doutor em Curitiba", capaz de realizar, conforme outros personagens condutores de outras cidades modelo, "um governo forte, personalizado, estável, apolítico, carismático, expressando a vontade unitária de toda uma cidade de manter a trégua e a coesão interna, a fim de afrontar, com base num projeto competitivo e no patriotismo cívico, as outras cidades" (VAINER, 2000, p. 97). Constitui-se, portanto, no protótipo de liderança urbana que predomina na cidadeempresa, cuja principal característica é a despolitização planejada.

O poder de seu discurso nos programas eleitorais não está propriamente no carisma de sua imagem pessoal ou no programa de governo que apresenta - cuja principal característica é reduzir o espaço da política do governo local à transformação da cidade em "um canteiro de obras, onde o curitibano colhe qualidade de vida" -, mas na estratégia de fazer desacreditar o discurso de seus oponentes, valendo-se de procedimentos de exclusão ${ }^{13}$. A contraposição entre "falar" e "fazer" é o

13 Sobre a produção do discurso, Foucault ressalta: "Em uma sociedade como a nossa, conhecemos, é certo, procedimentos de exclusão. O mais evidente, o mais familiar também, é a interdição. Sabe-se bem que não se tem o direito de dizer tudo, que não se pode falar de tudo em qualquer circunstância, que qualquer um, enfim não pode falar de qualquer coisa. Tabu do objeto, ritual da circunstância, direito privilegiado ou exclusivo do sujeito que fala: temos aí o jogo de três tipos de interdições que se cruzam, se reforçam ou se compensam, formando uma grade complexa que não cessa de se modificar” (FOUCAULT, 2000, p. 9; itálicos nossos). recurso mais utilizado: "Os outros fazem promessas fantasiosas que jamais serão cumpridas. [...] Falar é fácil. Fazer é com o Cássio. [...] Cássio fez. Cássio está fazendo. Cássio vai fazer um pouco mais... [...] Cássio fala pouco e faz. [...] Fala pouco, trabalha muito. [...] Cássio transforma problemas em soluções. [...] Um Prefeito que fez tantas obras não precisa fazer barulho. Cássio, um Prefeito que fala pouco".

Forte Netto, dissidente do grupo original dos urbanistas, apesar de se posicionar de modo crítico frente ao modelo, procura estabelecer sua imagem ao eleitorado valendo-se dos estereótipos do modelo. Numa criação também cuidadosa, sempre apresentando propostas ilustradas por mapas dinâmicos, ele é introduzido como o "arquiteto com capacidade técnico-urbanística" para dar continuidade à mesma forma de criar. Forte Netto alega que a cidade deu-lhe a oportunidade para se firmar enquanto profissional da Arquitetura, deulhe o reconhecimento profissional; agora, pretende, com idéias e ações inovadoras e com capacidade de realizar parcerias com a comunidade, retribuir o que a cidade lhe ofereceu. Buscará "soluções tecnicamente corretas", com "criatividade para encontrá-las e determinação para executá-las”. Em vários programas, o senador Álvaro Dias reapresenta-o como o candidato que cumpre "as exigências necessárias a um bom Prefeito: honestidade, capacidade técnica, competência administrativa, habilidade política e muita sensibilidade". A identificação do candidato com o ícone consagrado o urbanista - reforça a afinidade que sua condição técnica tem com o curitibano, e essa condição hipoteticamente lhe garante um completo grau de conhecimento da realidade e da população curitibana: "Você não me conhece, mas eu conheço como você vive".

Os demais candidatos não adotam para si o perfil técnico-urbanista. Tampouco dão voz ao curitibano construído pelo modelo, mas àquele que demonstra estar excluído de sua eficácia.

Ângelo Vanhoni parte da idéia de que há segregação social em Curitiba, posicionando-se contrário à "discriminação e a qualquer forma de exclusão", porque "todo mundo é igual, apesar de diferente". Numa peça contundente, cria uma seqüência de imagens de pessoas encapuzadas, falando cada um do seu próprio medo (violência, desemprego, solidão, drogas, que geram violência, velhice, assaltantes, trânsito). Conclui a peça 
quando retiram o capuz e dizem, cada um ao seu modo, que querem ser reconhecidos como gente. Simbolicamente, o candidato desmascara o curitibano embevecido com sua condição de morador de uma cidade-modelo. Propõe-se a "administrar junto com a comunidade" e caracteriza sua concepção de planejamento reforçando a premissa do planejamento da cidade do ponto de vista humano (em contraposição com urbano). Sua meta é que "Curitiba continue se embelezando cada vez mais, mas que se preocupe em tornar mais bela e mais rica a vida de cada um dos curitibanos".

Eduardo Requião investe em um discurso caracterizado por palavras de ordem que percorrem um ideário humanista: "Acreditar no homem: força e inteligência a serviço da vida"; "O direito do cidadão acima de tudo"; "As pessoas são mais importantes que o Estado"; "O Estado foi criado para facilitar a vida das pessoas"; ou "Miséria e desigualdade social restringem a liberdade de todos nós". Sua proposta é "discutir políticas e seus equívocos". Sobre política, veicula em seu discurso a idéia que "os políticos usaram palavras para iludir. Acreditem que a política pode transformar a realidade".

A ruptura, o abandono do discurso do urbanismo como "o discurso que procura identificar as 'patologias do espaço', e que entende a intervenção médica, técnico-científica, estética e despolitizada" (SOUZA, 1999, p. 11) norteia a construção da imagem da cidade revelada por Maurício Requião. Em sua crítica à "cidade dos cartões postais", vislumbra uma Curitiba a ser construída participativamente: "Juntos construiremos uma cidade melhor, não só nas aparências, mas no essencial - saúde, educação, segurança [...]. Eu vou ser Prefeito daqueles que anseiam pela ação do governo. Vou combater os parasitas e os aproveitadores colocando a Prefeitura a serviço dos bairros, dos assalariados, das pequenas empresas, dos desempregados, dos aposentados, de todos. Homens, mulheres, crianças, jovens, idosos. Todos que empregam sua vida na construção da nossa Curitiba e amargam em seu cotidiano o gosto do desamparo".

É para o território da crítica política e do desvendamento dos mitos da Curitiba cidademodelo que, mais que qualquer outro concorrente, direciona sua participação na mídia, identificando o candidato da situação com um grupo político ora envolvido em toda sorte de denúncias sobre corrupção ${ }^{14}$ (anexo 4). Com inserções curtas, relaciona-o com seus aliados em metáforas e comparações: "política como um jogo de cartas marcadas" (e sucedem, nas cartas de baralho, as fotos de seus aliados), "tango" (ao som do tango Amigos, dançam seus aliados), ou "é tudo caranguejo do mesmo barco" 15 .

Em seus programas, também "um outro curitibano" assume o papel principal. Não o curitibano da classe média, que desfruta da festejada qualidade de vida da cidade planejada, mas o curitibano que "não se sente amado" pela cidade e se diz abandonado à sua sorte. Este critica, à sua maneira, o projeto de cidade dos seus atuais governantes: "Faz quatro anos que não mexiam no bairro, agora passaram esse asfaltinho" (depoimento de morador da periferia); "eles não pensam na parte social das pessoas. Só fazem propaganda dizendo que o atendimento é bom" (usuária de posto de saúde). "Eles acham que os camelô da rua são bandido. Estão trabalhando pra levar o pão de cada dia para seus filhos. Emprego não tem. Já a propaganda do Cássio Taniguchi e Jaime Lerner diz que Curitiba é cidade do Primeiro Mundo, tem emprego. Os brasileiros vem tudo pra cá. Chega aqui não tem emprego, passam fome, vai morar debaixo do viaduto. E depois o que só resta fazer, ou virar bandido ou virar camelô" (depoimento de vendedora ambulante em blitz policial).

Na linha de desconstrução do modelo, Maurício Requião ironiza a propaganda veiculada em outdoors, do candidato-Prefeito, "Cássio, um senhor Prefeito", comentando: "mostra-se como um senhor Prefeito. Na nossa administração, senhor é o cidadão".

Para entender o impacto desses discursos, faz-

14 O PSTU também adentrou contundentemente no território da crítica política aos governantes, sendo alvo de suspensões contínuas de sua participação no horário político eleitoral, determinadas como direito de resposta a acusações nominais.

15 Sobre esse aspecto, é curioso notar que o discurso do candidato à reeleição se esquiva de qualquer identificação com o governo federal, do qual seu partido político compõe uma das bases fundamentais, e mesmo estadual, ou de qualquer referência aos problemas sociais, econômicos ou éticos do país. Sua postura - talvez mais que buscando não se desgastar diante de uma situação desfavorável - cristaliza uma ambigüidade escalar, manifestando as "ambições globais de administrações locais” (RIBEIRO \& DIAS, 2001, p. 2), sobrepassando, ou desconsiderando, as escalas nacional e estadual. 
se necessário uma breve reflexão acerca da visão liberal predominante de democracia, paradigma que vem, inclusive, determinando a compreensão do eleitor, que em diversas pesquisas de opinião tem se posicionado contrário a candidatos que apresentam críticas duras - denúncias de cunho político ou pessoal - a outros candidatos. Portanto, é compreensível que, do ponto de vista do marketing político, a maioria dos candidatos evite o antagonismo, intrínseco ao campo da política, e procure o território confortável da imagem do "gestor equilibrado com competência técnica".

Para Mouffe (1999), na concepção liberal a política é entendida como um processo racional de negociação entre indivíduos, destituída de uma dimensão de poder e antagonismo. O êxito do liberalismo político, por sua vez, dependeria da possibilidade de estabelecer as condições que fazem possível um tipo de argumentação que reconcilie a moral com a neutralidade. No entanto, a autora sustenta a impossibilidade de êxito da tentativa do discurso liberal de inventar um princípio de unidade social por meio da neutralidade com base na racionalidade.

Mouffe, ao analisar a dinâmica política das sociedades democráticas contemporâneas, considera preponderante o papel do poder e do antagonismo na constituição de um projeto de sociedade democrática: "El espacio político de la democracia no es un espacio neutro en el que se enfrentarían intereses en competencia y cuya topografía nos veríamos obligados a aceptar definitivamente, so pena de no respetar las reglas de juego democráticas. Se trata de un espacio cuya formación es expresión de las relaciones de poder, y éstas pueden dar lugar a configuraciones interiores muy distintas. Esto depende del tipo de interpretación dominante de los principios de legitimidad y de la forma de hegemonía que así se instaure. Pasar por alto esta lucha por la hegemonía imaginando que sería posible establecer un consenso resultante del ejercicio de la 'razón pública libre' (Rawls) o de una 'situación ideal de la palabra' (Habermas), es eliminar el lugar del adversario y excluir la cuestión propiamente política, la del antagonismo y el poder" (MOUFFE, 1999, p. 24).

Portanto, a realidade social só pode ser entendida por meio de sua articulação em relações de poder e o objetivo de uma política democrática, por conseguinte, "no es erradicar el poder, sino multiplicar los espacios en los que las relaciones de poder estarán abiertas a la contestación democrática" (ibidem). Na proliferação desses espaços, com vistas à criação das condições de um "autêntico pluralismo agonístico" - ou seja, de arenas de verdadeiro confronto de idéias conflitantes, no plano do discurso -, tanto no domínio do Estado quanto no da sociedade civil, circunscreve-se a dinâmica inerente à democracia radical e plural.

\section{III.1 DESCENTRALIZAÇÃO POLÍTICA E PAR- TICIPAÇÃO POPULAR}

Nas últimas duas décadas, a ampliação dos domínios da esfera pública no Brasil, tendo em vista a inclusão de atores não-estatais, vem estabelecendo uma nova institucionalidade. Com o advento do processo de descentralização ${ }^{16}$ de políticas setoriais, a partir da Constituição de 1988, foram criados inúmeros conselhos que deveriam se constituir em instâncias de participação de segmentos da sociedade no controle da gestão de políticas setoriais (basicamente saúde e assistência social) e programas governamentais específicos.

Contudo, observa-se na prática da gestão pública uma resistência, dos que detêm o poder, em abrir canais efetivos de debate sobre as políticas públicas. Para aqueles que exercem a arte de governar, vale a visão tradicional de separação entre Estado e sociedade civil. A "população aparece como sujeito de necessidades, de aspirações, mas também como objeto nas mãos do governo; como consciente, frente ao governo, daquilo que ela quer e inconsciente em relação àquilo que se quer que ela faça" (FOUCAULT, 1985, p. 289). Nesse sentido, com a incipiente organização da esfera pública no Brasil e, por conseguinte, com a inexistência de uma contratualização, passa-se uma procuração em branco aos governantes, sem a garantia de que o programa de governo, apresentado no momento da eleição, seja realmente cumprido pelo representante eleito.

De modo geral, no caso da campanha em Curitiba, a maioria dos candidatos apresentou, em seus discursos, idéias relacionadas à descentralização política e à participação popular, sem no entanto propor formas concretas de institucionalização, ou explicitar mecanismos de democratização das decisões. No entanto, especialmente

\footnotetext{
16 Sobre o processo de descentralização de políticas sociais no Paraná, ver Ribeiro et al. (1997).
} 
no final do primeiro turno, o ideário relacionado a visões de participação popular na definição do planejamento urbano passou a qualificar o discurso dos candidatos.

Nesse sentido, é interessante observar, no desenvolvimento do programa eleitoral, a trajetória da apresentação da imagem do Prefeito, candidato à reeleição. Nos primeiros programas, a sua capacidade de planejar isoladamente, ou com sua equipe, é enfatizada: "O Prefeito Cássio já planejou e vai implantar o metrô de Curitiba. [...] Antes que o problema apareça a gente apresenta uma alternativa. [...] O traçado do novo metrô é coerente à visão estratégica que temos de Curitiba". Contudo, o questionamento em bloco dos candidatos oposicionistas, com relação à excessiva centralização das decisões das políticas públicas implementadas na cidade, somado à perda de sua posição hegemônica em diferenciadas pesquisas de intenção de voto, provoca sutil mudança. O programa passa a veicular cenas do Prefeito em reuniões comunitárias, como aquela em que se diz: "O pessoal já está acostumado. De repente chega o japonês. Cássio não faz discurso. Toda reunião é uma conversa franca [...] Cássio e sua equipe anotam tudo e, a partir daí, ele começa a tomar decisões". A idéia de constituir um Conselho Comunitário do Cidadão e criar Núcleos de Proteção ao Cidadão é apresentada em seu programa sobre segurança, porém a sua função não é especificada.

Já no programa do candidato Ângelo Vanhoni, a participação é mencionada seguidamente, em diferenciadas propostas, no sentido de "integrar ações com participação da comunidade". Ressalta que a "qualidade de um Prefeito é administrar junto com a comunidade, discutir com firmeza e coragem, acreditando e garantindo credibilidade". Adquire centralidade na proposta do orçamento participativo, que se constitui no instrumento de reforma do Estado de maior visibilidade nacional da prática de administração municipal do Partido dos Trabalhadores. Proposta também mencionada pelo candidato Eduardo Requião, que defende a descentralização da Prefeitura em dez subPrefeituras "com autonomia orçamentária e operacional" e "orçamento participativo [...] pondo fim ao assistencialismo perverso".

O tema descentralização aparece, com destaque, no programa de Forte Netto, que critica a "excessiva centralização na maneira de administrar a cidade", enfatizando que "descentralizar é um jeito de administrar Curitiba de forma igual para todos". Em seu discurso, Forte Netto enfatiza: "Como cidadão, eu não aceito o modelo que ajudou a criar tantas diferenças; [...] sofremos com os problemas, temos o direito de participar nas soluções". Propõe "olhar para todos os bairros com os mesmos olhos" e promover um "desenvolvimento urbano mais democrático e mais justo, trabalhando em conjunto com a comunidade". A descentralização que norteia as propostas de campanha é didaticamente traduzida: "Em futebol, descentralizar é jogar pela pontas, [...] na administração, é usar melhor as verbas, levar para a periferia; [...] vamos organizar os bairros em oito comunidades que articularão atividades e investimentos de Curitiba, [...] cobrar menos impostos para quem quer montar um negócio fora do centro da cidade; [...] a descentralização aquecerá negócios e gerará empregos; [...] descentralização é o mesmo que desenvolvimento".

Convém ressaltar que, apesar de o termo descentralização estar constantemente associado a idéias de fortalecimento da democracia e ao redesenho da esfera das decisões públicas no imaginário político contemporâneo, há uma controvérsia entre diversos autores acerca de seu significado conceitual. Medidas meramente de repasse de competências no interior de uma mesma estrutura administrativa e, por conseguinte, de impacto restrito no que concerne a uma real mudança no seu padrão decisório, vêm sendo equivocadamente denominadas como descentralização. Cabe, para esta análise, estabelecer a distinção entre os termos desconcentração e descentralização. Apesar de constituírem conceitos de conteúdos distintos, são usualmente confundidos ou utilizados como sinônimos.

"Uma distinção fundamental entre descentralização e desconcentração é aquela proposta por Boiser [1990], que diz: 'Enquanto a desconcentração designa a transferência de capacidade decisória de um nível a outro de uma estrutura administrativa dentro da própria organização, a descentralização é um conceito mais complexo, pois reconhece competência a organismos independentes juridicamente do Estado e que possuem personalidade jurídica, receitas e normas de funcionamento próprias"” (RIBEIRO et al., 1997, p. 33).

Para compreender a resistência a modalidades de ampliação dos canais de participação dos seg- 
mentos não-estatais na definição de políticas públicas, cabe destacar que o Estado brasileiro sempre se caracterizou por exacerbado centralismo. Essa condição se reflete diretamente em nossa cultura política, ocasionando, inclusive uma grande relutância nos mais diferenciados setores da sociedade civil em aceitar proposições de experiências de democracia direta. Um exemplo ilustrativo é a propaganda da candidatura do PFL, que foi veiculada na campanha do segundo turno, momento de polarização de posições PFL-PT. A propaganda ironizava a democracia direta por meio da imagem de um ônibus urbano, cujo trajeto só seria definido após uma assembléia entre os passageiros. Os estereótipos, particularmente contrários à idéia do orçamento participativo, foram bem explorados - confusão, conflitos, perda de tempo - e, apesar do estilo debochado da situação inusitada, a peça reproduziu, com sucesso, a idéia hegemônica que a maioria da população tem dos canais de democracia direta.

Essa resistência a ampliar os canais de participação também é percebida na ausência do fenômeno metropolitano no discurso eleitoral. Governar uma cidade que há muito tempo transpôs suas próprias fronteiras territoriais exige pactos intermunicipais que viabilizem o desempenho das funções públicas de interesse comum. No entanto, o discurso dos candidatos manteve presente apenas uma idéia de descentralização que resulta na replicação do exercício de "um poder" sobre vários fragmentos da cidade, sem cogitar da necessidade da articulação de "outros poderes", oriundos das demais municipalidades, constituindo um fórum agregador - condição única para que se conquiste eficácia na gestão de um espaço que é inegavelmente aglomerado.

\section{CONSIDERAÇÕES FINAIS}

$$
\begin{array}{r}
\text { Agora não se fala mais } \\
\text { toda palavra guarda uma cilada } \\
\text { e qualquer gesto é o fim } \\
\text { do seu início. } \\
\text { Torquato Neto (1971) }
\end{array}
$$

Mais com paráfrases - no sentido de retorno aos mesmos espaços do dizer, reproduzindo-se o dizer estabilizado, sedimentado - que com polissemias - no sentido de ruptura dos processos de significação, no espaço da criatividade (MANOEL, 2001) -, fez-se o discurso eleitoral do primeiro turno à sucessão da Prefeitura em Curitiba. $\mathrm{O}$ tom dos últimos pronunciamentos $\mathrm{e}$ os resultados das urnas revelaram possibilidades de mudanças em curso.

"Algo novo está acontecendo na cidade!" Com essa constatação, fundada na certeza do segundo turno, a campanha de Ângelo Vanhoni chama a atenção do eleitor de que novas propostas estão sendo bem-vindas ao curitibano: "É primavera de uma nova cidade. Curitiba está mudando, como dizia nosso poeta Paulo Leminski”. Uma mudança sem grandes revoluções - na tela, imagens dos ícones da cidade com flores, crianças alegres; ao fundo, a música Mudança de estação, de Leminski.

Talvez o tom cauteloso de suas críticas, a promessa de moralidade e a experiência administrativa do Partido dos Trabalhadores, salientada pela mídia nacional e sintetizada na griffe "modo petista de governar", tenham gerado simpatia em grande parte do eleitorado e conduzido Ângelo Vanhoni ao pleito final.

Nem mesmo os depoimentos de pessoas nas ruas, insistentes nos derradeiros programas de Cássio Taniguchi - "Não pode mudar [...] Tem que continuar" -, ou o apelo emocionado do governador Jaime Lerner, nos momentos finais da campanha, desmotivaram essa opção por mudança. Um apelo que, mais uma vez, enfatizou o "patriotismo cívico": "Você que sempre foi nosso eleitor, mas optou até aqui por outros candidatos, o meu respeito. Você já demonstrou o seu apreço por eles. No entanto as pesquisas mostram que todos estão muito distantes do Cássio. O Cássio, candidato do coração curitibano, tem mais voto que todos os outros somados. Então, pense um pouco comigo. Se a grande maioria vota no Cássio, por que retardar o que a maior parte do povo já decidiu? Vamos eleger o Cássio agora no primeiro turno. Eu te peço isto, não contra sua primeira opção. Eu te peço isto pela nossa cidade. Eu te peço isto por Curitiba".

Ciente de que a imagem carece de alicerces, o candidato da situação muniu-se de todas as armas que a tecnologia da comunicação podia lhe fornecer; reforçou as composições políticas, garantiu um elevado aporte financeiro e consolidou sua campanha. Mesmo assim, sua vitória no turno final se deu pela pequena margem de $2 \%$ de votos. $\mathrm{O}$ "susto" de uma possível derrota fez que o apelo do "social", já maximizado no final do primeiro turno - "Curitiba: cidade com a mão estendida para praticar a inclusão social" - se tornasse a principal proposição do discurso no segundo turno. 
Essa era a forma de responder às críticas que perpassaram todas as candidaturas no turno inicial, e principalmente, de enfrentar as propostas petistas, voltadas a essa tônica. Tanto foi que, eleita, a nova administração assume como lema "Curitiba, a capital social".

Essa ênfase no "social" resume a existência de um campo simbólico no qual se trava a luta política pela reprodução da hegemonia, ameaçada pelo conflito trazido por outras leituras da cidade. Nelas, vê-se que há uma crescente desconfiança por parte dos curitibanos quanto aos mitos que sustentam a imagem de cidade-modelo, resultando em uma abertura, ainda que limitada, a novas posturas, desde que não desconstruam essa imagem que tão deleitosamente povoa o seu senso comum e consolida seu conforto. Posturas sem críticas contundentes, que agridem seu imaginário e podem surtir um efeito contrário.

O espetáculo da cidade atrativa, competitiva, já não é suficiente para tornar a realidade tão irreprovável, embora ainda neutralize práticas de resistência e dificulte a emergência de sujeitos políticos, efetivamente comprometidos com a produção coletiva da cidade. A participação à distância - em prática reforçada nas propostas de informatização dos canais de participação do candidato vitorioso - e a persuasão ideológica da mídia ainda exercem um forte controle social e facilitam o exercício do poder hegemônico.

Independentemente do resultado das urnas, o antagonismo, a pluralidade de posições e os comportamentos peculiares entre os candidatos permitiram que fosse instaurado um debate que, no conjunto, acabou por fazer uma leitura crítica do consenso sobre a eficácia do modelo Curitiba, mesmo que não o tenha desconstruído, preservando-o em propostas que admitiam mudanças em seu conteúdo, mas persistiam aprisionadas em suas intenções.

O discurso da oposição deixou textual a urgência de políticas públicas de cunho social que venham a dar conta das demandas desatendidas que ameaçam a "qualidade de vida" do pólo metropolitano, especialmente no tocante à contenção da violência urbana. Seu discurso também destacou a necessidade da participação cidadã, não aquela do mero espectador que referenda decisões que lhes são impostas, mas a do verdadeiro cidadão, com livre direito à reflexão e à crítica, despertando compromissos e responsabilidades. E, o mais importante, reportouse à premência da lisura administrativa, da probidade e da transparência na gestão pública.

Considerado o mérito da vitória do discurso da globalização, sob intencionalidades externas mas muito bem representado nas coalizões locais, e percebido o fato de que tenha perpassado - por opção ou mera reprodução - pela superfície do discurso dos candidatos, a vitória que obteve evidenciou que, ao menos no âmbito do eleitor, o pensamento sobre a cidade já se torna diverso ${ }^{17}$. As demonstrações de esgotamento do modelo, mesmo que comedidas, deixam perceber que se fazem acompanhar pela emergência de outros processos, de novos movimentos sociais, às vezes invisíveis ou invisibilizados pelas técnicas filtradas de construção da imagem urbana, apoiada apenas em segmentos escolhidos e não fruto da miríade de leituras da cidade.

Quiçá venham contrapor-se à racionalidade "totalitária", hegemônica, e passem a ocupar a pequena margem deixada por esta para a variedade, a criatividade, a espontaneidade, o contraditório, como as "contra-racionalidades e racionalidades paralelas", analisadas por Santos (2000), que conseguem escapar ao totalitarismo da racionalidade dominante, ou as "mini-racionalidades internas", apontadas por Souza Santos (1999), que, conscientes de uma "irracionalidade global", exercem o seu combate local. Nessas leituras, os excluídos (do mercado, dos direitos, do exercício cidadão de um poder coletivo) percebem que a globalização não é um dado natural, um fato irreversível, um ato de benevolência, e agem no sentido de questionar a produção e manutenção da ideologia hegemônica e provocar a mudança histórica. Como afirma Santos, esta terá como atores principais "o indivíduo liberado partícipe das novas massas e não o 'homem acorrentado'; o pensa-

17 Esta conclusão ampara-se também na mudança constatada na composição da Câmara dos Vereadores na última legislatura. Considerando, dentre os componentes da Câmara Municipal, como partidos de oposição o PT e o PMDB, essas bancadas se mantiveram com sete vereadores eleitos tanto em 1992 quanto em 1996 (três do PT e quatro do PMDB, e este com a ressalva de que parte de seus integrantes votaram projetos com a base governista); nas eleições de 2000, embora o PMDB tenha reduzido sua bancada para três vereadores, o PT elegeu seis candidatos, dobrando sua bancada, e o PDT, antiga base governista, explicitou sua oposição ao governo, ampliando a frente oposicionista para 11 vereadores. 
mento livre e não o discurso único" (SANTOS, 2000, p. 14).

Esses novos movimentos, mesmo tímidos, estão em multiplicação, e as soluções que gestam, a princípio singelas, são ricas em legitimidade, transformadoras, capazes de romper, aos poucos, os simulacros do poder. Bem no caminho do que diz Souza Santos: "São soluções movediças, radicais no seu localismo. Não interessa que sejam portáteis ou mesmo soluções de bolso. Desde que expludam [sic] nos bolsos" (SOUZA SANTOS, 1999, p. 111).

Recebido para publicação em 4 de junho de 2001.

Rosa Moura (rmoura@pr.gov.br) é geógrafa do Instituto Paranaense de Desenvolvimento Econômico e Social (IPARDES), Professora da disciplina "Produção do Espaço Metropolitano" no Curso de Especialização em Análise Ambiental do Departamento de Geografia da Universidade Federal do Paraná (UFPR).

Thaís Kornin (k_thais@ @otmail.com) é especialista na área de gestão pública pelo Instituto Nacional de Administração Pública, de Madri e pesquisadora do Instituto Paranaense de Desenvolvimento Econômico e Social (IPARDES).

\section{REFERÊNCIAS BIBLIOGRÁFICAS}

ACSELRAD, H. 1999. Discursos da sustentabilidade urbana. Revista Brasileira de Estudos Urbanos e Regionais, Campinas, ANPUR, n.1, p.79-90, maio.

ARANTES, O. B. F. 2000. Uma estratégia fatal : a cultura nas novas gestões urbanas. In : ARANTES, O., VAINER, C. \& MARICATO, E. (orgs.). 2000. A cidade do pensamento único : desmanchando consensos. Petrópolis : Vozes.

AUGÉ, M. 1994. Não-lugares : uma introdução à antropologia da pós-modernidade. Campinas : Papirus.

BENACH, N. \& SÁNCHEZ, F. 1999. Políticas urbanas y producción de imágenes de la ciudad contemporánea. In : CARRIÓN, F. \& WOLLRAD, D. (eds.). La ciudad, escenario de comunicación. Ecuador : FLACSO.

BENKO, G. 1994. Breve exame do mundo pósmoderno. In : SANTOS, M., SOUZA, M. A. A. \& SILVEIRA, M. L. (orgs.). Território : globalização e fragmentação. São Paulo : Hucitec/ANPUR.

BOISIER, G. 1990. La descentralización : un tema difuso y confuso. Santiago : ILPES.

BORJA, J. \& CASTELLS, M. 1996. As cidades como atores políticos. Novos Estudos CEBRAP, São Paulo, n. 45, p. 152-166, jul.

BORJA, J. \& FORN, M. 1996. Políticas da
Europa e dos Estados para as cidades. Espaços e debates, ano XVI, no 39, p. 32-47.

BOURDIEU, P. 1998. Contrafogos : táticas para enfrentar a invasão neoliberal. Rio de Janeiro : Zahar.

CASTRO SANTOS, M. H. 1997. Governabilidade, governança e democracia : criação de capacidade governativa e relações executivolegislativo no Brasil pós-constituinte. Dados, Rio de Janeiro, v. 4, n. 3, p. 335-376.

FOUCAULT, M. 1985. Microfisica do poder. $5^{\mathrm{a}}$ ed. Rio de Janeiro : Graal.

. 2000. $A$ ordem do discurso. $6^{\mathrm{a}}$ ed. São Paulo : Loyola.

HARVEY, D. 1996. Do gerenciamento ao empresariamento : a transformação da administração urbana no capitalismo tardio. Espaço e debates, São Paulo, NERU, v. 16, n. 39, p. 48-64.

IRAZÁBAL, C. 2000. The Multicultural City. Ethnicity, Tradition and Urban Space : Architecture and the Production of Postcard Images; Invocations of Tradition vs. Critical Regionalism in Curitiba. Curitiba : mimeo.

MANOEL, M. 2001. Sujeitos de linguagem. Texto produzido para o I Encontro Pedagógico dos Professores do UNICENP/Núcleo de Ciências Humanas e Sociais Aplicadas. Curitiba : mimeo.

MELO, M. A. B. C. 1995. Ingovernabilidade : 
desagregando o argumento. In : VALLADARES, L. (org.). Governabilidade e pobreza. Rio de Janeiro : Civilização Brasileira.

MOUFFE, C. 1999. El retorno de lo político : comunidad, ciudadania, pluralismo, democracia radical. Barcelona : Paidós.

MOURA, R. 2000. Regulación de uso del suelo urbano : discusión sobre el caso de Curitiba. Trabalho produzido para o workshop "Law and Urban Space". International Research Group on Law and Urban Space, Cairo, jun. mimeo.

OLIVEIRA, D. 1995. A política do planejamento urbano : o caso de Curitiba. Campinas. Tese (Doutorado em Ciências Sociais). Universidade de Campinas.

RIBEIRO, A. C. T. 1999. Conversando sobre espaço. Texto apresentado no VIII Encontro Nacional da ANPUR, Porto Alegre, mai. Mimeo.

RIBEIRO, A. C. T. \& DIAS, L.C. 2001. Escalas de poder e novas formas de gestão urbana e regional. Anais do IX Encontro Nacional da ANPUR. Rio de Janeiro : ANPUR, v. 1, p. 1-4.

RIBEIRO, D. M., RAGGIO, N. Z., KORNIN, T. \& VILLA VERDE, V. 1997. A descentralização das políticas sociais no Paraná. Revista paranaense de desenvolvimento, Curitiba, IPARDES, n. 90, p. 31-51, jan.-abr.

SALLAS, A. L. F. (coord.). 1999. Os jovens de Curitiba: desencantos e esperanças. Juventude, violência e cidadania. Brasília : UNESCO.

SÁNCHEZ, F. 1999. Arquitetura e urbanismo : espaços de representação na cidade contemporânea. Veredas, Rio de Janeiro, Centro Cultural Banco do Brasil, v. 4, n. 41, p. 26-29, maio.

SÁNCHEZ, F. \& MOURA, R. 1999. Cidadesmodelo : espelho de virtude ou reprodução do mesmo? Cadernos IPPUR, Rio de Janeiro, v. 13, n. 2, p. 95-114, ago.-dez.

SANTOS, M. 2000. Por uma outra globalização : do pensamento único à consciência universal. $2^{\mathrm{a}}$ ed. Rio de Janeiro/São Paulo : Record.

. 2001. Quem está na frente é o povo. Entrevista concedida a Carlos Tibúrcio e Sílvio Caccia Bava. Especial n. 2, Um outro mundo urbano é possível. Cadernos Le Monde Diplomatique, São Paulo, Instituto Abaporu, p. 47, jan. Edição especial.

SOUZA SANTOS, B. 1999. Pela mão de Alice : o social e o político na pós-modernidade. $5^{\text {a }}$ ed. São Paulo : Cortez.

SOUZA, N. R. 1999. Planejamento urbano, saber e poder : o governo do espaço e da população em Curitiba. São Paulo. Tese (Doutorado em Sociologia). Faculdade de Filosofia e Ciências Humanas, Universidade de São Paulo.

VAINER, C. 2000. Pátria, empresa e mercadoria : notas sobre a estratégia discursiva do planejamento estratégico urbano. I $n$ : ARANTES, O., VAINER, C. \& MARICATO, E. (orgs.). $A$ cidade do pensamento único : desmanchando consensos. Petrópolis : Vozes.

ZUKIN, S. 1991. Landscape of Power. From Detroit to Disney World. Los Angeles : University of California Press.

. 1992. The City as a Landscape of Power. In : BUDD, L. \& WHIMSTER, S. (orgs.). Global Finance and Urban Living. Londres : Routledge.

WACQUANT, L. 2001a. As prisões da miséria. Rio de Janeiro : Jorge Zahar.

. 2001b. Punir os pobres : a nova gestão da miséria nos Estados Unidos. Rio de Janeiro : Freitas Bastos.

\section{ANEXO $1^{18}$ - PERFIL DO CANDIDATO E DA CAMPANHA}

Ângelo Vanhoni - vice José Maurino (Coligação Curitiba vida melhor - PT/PPS/PV/PCB/PC do B/PMS/PMN)

Características: leveza, crítica sutil

Mote principal: "Pense novo, pense diferente, a cidade quer ser gente"

Principal jargão: "gente"

Imagem dominante: pessoas comuns muito alegres, abraçando-se

Propostas: "programa vida melhor", reproduzindo as propostas nacionais do PT, de cunho social,

18 Todos os anexos referem-se ao $1^{\underline{\underline{a}}}$ turno da campanha à Prefeitura de Curitiba, em outubro de 2000. 
após breve análise da situação curitibana, sucedida por metas para o primeiro ano de governo

Cássio Taniguchi - vice Beto Richa (Movimento Curitiba sempre com você - PFL coligado a PTB/PPB/PTN/PSC/PSB/PST/PRP/PSD/PSL/PT do B/PL/PRN)

Características: mostra da eficiência do que está sendo oferecido "pelo Cássio" como Prefeito

Mote principal: "Vou de novo, vou de Cássio"

Principal jargão: sorriso "singelo", aparente "simplicidade"

Imagem dominante: seleção dos ícones urbanos

Propostas: sempre dando continuidade a ações já desenvolvidas, e indo além. Sem uma sequiência, misturadas no meio de longos programas, com apelos de várias ordens, apoiadas em ilustrações características dos "arquitetos", saindo de pranchetas, posteriormente explicadas pelo candidato. Apresentadas muito rapidamente, numa sucessão de palavras-propostas, dando a impressão de que o tempo é curto para tanta coisa.

\section{Diego de Sturdze - vice Júlio (PSTU)}

Características: crítica pesada

Mote principal: "contra burguês, vote 16!"

Principal jargão: "contra tudo isso aí, fora FHC e FMI!"

Imagem dominante: montagens em seqüências de quadros com ação policial em atos de expulsão de sem-terras; recortes de jornais com denúncias ao governo; som local

Propostas: palavras de ordem contra o sistema e seus dirigentes

\section{Eduardo Requião - vice Prof a Yara (PDT)}

Características: humanismo, fala reflexiva, séria, tom monótono

Mote principal: "pela vida com dignidade"

Principal jargão: "nós temos que ter"

Imagem dominante: a bandeira brasileira sendo tecida por uma criança

Propostas: dispersas, de cunho humanista

\section{Jamil Nakad - vice Marta Mônica (PRTB)}

Características: tom hilário

Mote principal: "28 neles, Curitiba!"

Principal jargão: "Ladrão? Chega de ladrão!", "Chega dos mesmos!”

Imagem dominante: um número 28 com uma vassoura nas mãos expulsando da base da tela uma porção de porquinhos

Propostas: apresentadas caoticamente

\section{Luiz Forte Netto - vice Professor Kolb (Coligação Curitiba Forte - PSDB)}

Características: sempre introduzido por Álvaro Dias

Mote principal: "Por uma Curitiba cada vez mais forte"

Principal jargão: "Você e eu vamos fazer"

Imagem dominante: analogia com a urna eletrônica - mostra a realidade, aperta o "corrige" e apresenta a proposta

Propostas: pautadas em alguma proposição oriunda de segmentos articulados da sociedade, apresentadas diante de um mapa, com efeitos gráficos em movimento e ilustrações claras

\section{Maurício Requião - vice Moreno (Coligação das Oposições - PMDB/PAN)}

Características: denúncias e críticas

Mote principal: "Prá dizer não a tudo isso, o voto certo é no Maurício"

Principal jargão: "Juntos"

Imagem dominante: matérias da mídia complementadas com críticas e com mais informações ou entrevistas a populares

Propostas: apresentadas em partes, em mais de um programa 


\section{ANEXO 2 - ALGUMAS PEÇAS PUBLICITÁRIAS}

Ângelo Vanhoni-José Maurino ${ }^{19}$

A cidade quer ser gente

Palma da mão: cinco propostas de educação

Banco do Povo; Bolsa Escola; Creche Educacional; e outras sínteses de propostas

\section{Cássio Taniguchi-Beto Richa}

O "trenzinho" (onomatopéia das realizações)

Classificados ("quando você está procurando alguém que faça bem feito, exige experiência. Por que para Prefeito seria diferente?")

Obras sem som ("um Prefeito que fez tantas obras não precisa fazer barulho".)

"Tem candidato que diz que vai fazer [...]. Falar é fácil. Fazer é com o Cássio"

"Cássio fez. Cássio está fazendo (imagens com as 25 obras). Cássio vai fazer um pouco mais".

"Com saúde não se brinca. [...] Seriedade faz bem à saúde"

Programa 2000 (pessoas segurando sapato sujo de barro na mão sorrindo)

MST: Afinal o que mudou? Mudou o MST? Mudaram estes políticos?

Sala de aula (aluno colando de aluno nissei (...) Professora percebe a cola e faz cara feia)

Bandeira branca se transforma em vermelha enquanto voz em off cogita de ameaça à paz curitibana

Ênfase na marca "coração curitibano" que vira lampadazinha ("Eu vou de Cássio com a cabeça e o coração")

"Para onde vai esse ônibus?" (segundo turno)

\section{Diego de Sturdze-Júlio}

Contra tudo isso aí, fora FHC e FMI!

Pela reforma agrária com lutas do MST e dos trabalhadores urbanos

\section{Eduardo Requião-Prof ${ }^{a}$ Yara}

"Quem tem cabeça, vota no cabeça branca".

"Fique ao lado daqueles que acreditam na vida".

\section{Jamil Nakad-Marta Mônica}

"Chega dos mesmos!"

Apoio de Collor ("Collor nunca foi condenado por tribunal algum; perdeu seus direitos pois nunca se abaixou para os poderosos. Collor ajudou você a ser feliz")

\section{Luiz Forte Netto-Professor Kolb}

"O doente não pode ficar indo de um lado para outro...."

Segurança (número de delitos); outras propostas da campanha

Valdemar Niclevics: "Vim falar de escaladas. Mas desta vez, não é a minha. É a escalada do Forte Netto. Toda subida começa do zero. Para continuar até o topo, é preciso acreditar".

"Você tem sorte de ter um candidato forte!"

\section{Maurício Requião-Moreno}

Paródia à propaganda do "trenzinho" (obras do Cássio), apresentando um trenzinho com os apoios políticos a Cássio (Jaime Lerner, Rafael Greca, Emília Belinatti, Antônio Belinatti)

Analogias: "política como um jogo de cartas marcadas"; "cama de gato" (terminando com um nó no barbante e uma confusão de mãos e dedos trançados); "tango Amigos" (dançarinos com montagem fotográfica de Lerner e outros apoios), "É tudo caranguejo do mesmo barco"

Trenzinho - "Tem que mudar, tem que mudar a situação. Curitiba é do povo, é Maurício Requião"

19 Por economia de espaço e para evitar repetições, indicamos apenas os candidatos a Prefeito e vice-Prefeito. 


\section{ANEXO 3 - PROPOSTAS DE POLÍTICAS SOCIAIS}

\section{Ângelo Vanhoni-José Maurino}

Mulher - Secretaria da Mulher; políticas que garantam os direitos da mulher; linha especial para mulheres chefes de família no Banco do Povo; casas de abrigo, atendimento jurídico psicológico para mulheres e crianças vítimas de violência

Cidadania - não à discriminação e a qualquer forma de exclusão; cidade justa

Educação - Creches Educacionais (0-6 anos); novas creches com horário adequado às mães (sem férias, com aumento e revezamento de funcionários); melhoria do atendimento (saúde, alimentação, afeto educação); Multi-escola (6-14 anos); Meu Primeiro Emprego (14-18 anos); Recomeço (maiores de 40 anos); Terceira Idade Feliz (reintegração da pessoa idosa, feira mensal da terceira idade); Universidade Livre do Conhecimento; Bolsa Escola (1 salário mínimo para famílias de baixa renda com crianças de 7 a 14 anos na escola)

Serviço público - compromisso com a melhoria dos serviços públicos; turno de 6 horas; valorização dos funcionários públicos; plano de cargos e salários; correção de perdas salariais

Emprego - Banco do Povo (empréstimos com juros baixos a quem quer começar o próprio negócio, ou comprar equipamentos); Meu Primeiro Emprego (subsidiado por benefícios fiscais); estágios remunerados para jovens que permaneçam na escola

Habitação e meio ambiente - Minha Casa, com custo de $20 \%$ do salário mínimo; políticas habitacionais para evitar a agressão sistemática ao meio ambiente

Transporte coletivo e trânsito - ouvir a comunidade no caso do metrô; transparência na administração de planilha, revertendo em benefícios sociais; passe escolar; um domingo livre de tarifa todo mês; fim da punição (reeducar e conscientizar para o trânsito)

\section{Cássio Taniguchi-Beto Richa}

Mulher - atenção social diferenciada para todas as idades

Educação - escola municipal aberta para a comunidade (teatro, capacitação, música); Recreio Comunitário (canchas abertas em fins de semana, mural para artes, eventos); aproximar a família; compartilhar a vizinhança; Escola Especial Sul (equipamentos para necessidades especiais, terminal de ônibus do ensino especial, também para maiores de 25 anos)

Saúde - informatização do sistema; unidades 24 horas Pinheirinho e Cajuru; Pronto Socorro 24 horas psiquiátrico; unidade de saúde Mãe Curitibana (mulheres e crianças); Crescendo com Saúde (até 12 anos, doenças respiratórias); saúde para a $3^{a}$ idade no posto Ouvidor Pardinho; Vale Vovó; novos postos de saúde; Médico de Família; dentista na casa das pessoas; Fazenda Solidariedade (remédios de ervas)

Emprego - os Fazedores (orientação, aperfeiçoamento, trocas de experiências, ensino aos jovens que "estão querendo começar"); Rede do Conhecimento, informatizada; Crédito Solidário, através do Banco da Mulher

Urbanização - remoção da população das margens do lago das vilas Rosa e Concórdia e das áreas de risco na Vila Verde

Segurança - Núcleo de Proteção ao Cidadão; Conselho Comunitário do Cidadão; rede de iluminação pública; programas de esporte para afastar os jovens da criminalidade; cartões de segurança no sistema de transporte público, para a proteção do cobrador

\section{Diego de Sturdze-Júlio}

Políticas públicas contra a fome e o caos

Reforma agrária

\section{Eduardo Requião-Prof ${ }^{a}$ Yara}

Cidadania - valorização da vida, do ser humano, respeito, direito de manter relações afetivas, lazer, esporte, trabalho, segurança, justiça social 
Educação - escola em tempo integral (cidadã);

Cultura - atividades no final de semana feriados; artistas populares nos bairros; mais recursos da Fundação Cultural para projetos nos bairros

Emprego - apoio às pequenas e micro empresas, geração de mais empregos

Segurança - Secretaria Municipal de Segurança Pública; programa para trazer segurança às praças; escolas; trabalho

\section{Jamil Nakad-Marta Mônica}

Jovem - Secretaria da Juventude

Educação - dobrar o salário do professor; merenda fresca nas escolas; Bolsa Escola ( $\$ 70,00$ por mês); passe livre ao estudante; escolas municipais com ensino de supletivo; Universidade de Curitiba (gratuita para os pobres)

Emprego - programa de geração de empregos com cooperativas de coleta e reciclagem de lixo; construção de calçadas com o pessoal dos bairros; Banco Popular, para financiamento de máquinas

Habitação - construção de moradias populares

Segurança - Polícia Comunitária ("bandido só fica onde não tem polícia”)

\section{Luiz Forte Netto-Professor Kolb}

Mulher/criança - creches, maior tempo de permanência nas escolas, esportes, capacitação, políticas de emprego, conselho de mulheres com direito à voz

Educação - pré-escola, ensino fundamental em período integral com esportes e recreação; ensino especial integrado ao normal e sua ampliação; $3^{\circ}$ grau, com ensino à distância, aos professores; incentivo remunerado à qualificação; passe escolar (renda familiar de até 5 salários mínimos)

Saúde - medicina preventiva (vacinas, combate à AIDS e drogas, pré-natal, amamentação, respeito à dignidade); 8 novos centros de atendimento integral; pronto socorro infantil; novos postos de saúde e terceiro turno, com cooperativa de médicos; ambulâncias e farmácias em todo posto; fábrica de medicamentos

Emprego - programa do $1^{\circ}$ emprego, com subsídios tributários, associado a curso profissionalizante; criação de novas atividades e postos de trabalho; apoio ao comércio de bairro (calçadões; shoppings a céu aberto); microcrédito, central de emprego, apoio a empresas e trabalhadores autônomos; política de estímulo a segmentos com uso intensivo de mão-de-obra (fomento à construção civil e ao turismo)

Habitação - facilidades para construção, ampliação e reformas; facilidades no uso do solo, regularização; acesso ao financiamento para compra do imóvel ou material via COHAB; urbanização com projetos integrados de ação social (asfalto, meio-fio, calçadas) com apoio profissional das universidades; transformar favelas em "bairros dignos"

Segurança - policiamento preventivo nos bairros; aumento do efetivo; aumento número veículos para patrulhamento; maior cuidado na concessão de alvarás para funcionamento de casas noturnas; vigilância nas estações-tubo

\section{Maurício Requião-Moreno}

Criança - novas creches; transferência das creches para Secretaria de Educação; pré em todas as escolas municipais

Educação - Instituto Superior de Educação, com cursos gratuitos para os professores; dignidade e condições de aperfeiçoamento aos professores; plano de cargos e salários;

Cultura - investir em cultura, esporte e lazer

Saúde - transformar o sistema público de saúde (garantir exames, médicos nos postos, internação e remédios)

Emprego - geração de empregos; apoio à micro e pequena empresa; facilidades na concessão de alvarás, redução do IPTU e ISS; apoio para empréstimos; Fundo Público de Aval (empréstimos de até $\mathrm{R} \$ 5$ mil e crédito com juros abaixo do mercado); apoio às empresas curitibanas 
Habitação - Casa da Família (oferta de moradias para população de baixa renda); renegociar a dívida dos mutuários da Cohab; empréstimos para reforma e ampliação; urbanização de favelas com segurança; regularização fundiária, saúde, saneamento (tratamento e coleta de esgotos aos bairros e cuidados como o meio ambiente)

Segurança - Rede Integrada de Segurança (módulos nos bairros, policial da família); Secretaria Municipal de Segurança Pública

\section{ANEXO 4 - PRINCIPAIS DENÚNCIAS \\ Ângelo Vanhoni-José Maurino \\ Maltrato aos professores da rede pública (imagens de manifestações) \\ Problemas nacionais: desemprego; corrupção (apresentado também por Ciro Gomes)}

\section{Cássio Taniguchi-Beto Richa}

Resposta acusativa às críticas dos demais candidatos

\section{Diego de Sturdze-Júlio}

Contra a fome, o caos, a dívida externa; expulsar o FMI; contra FHC, Cássio e Lerner

Ação policial em atos de expulsão de sem terras

Recortes de jornais com denúncias a ações do governo contra a sociedade

\section{Eduardo Requião-Prof ${ }^{\mathrm{a}}$ Yara}

Crítica à falta de vontade política

"Eles querem impedir o desenvolvimento da sensibilidade humana"

\section{Jamil Nakad-Marta Mônica}

Reeleição; corrupção (“Ladrão? Chega de ladrão!")

Pedágios até em banheiros públicos

Ameaça de despejo sob não pagamento do IPTU

\section{Luiz Forte Netto-Professor Kolb}

Narcotráfico e crime organizado incrustados na estrutura do governo estadual, desmanche de carros Má aplicação dos recursos públicos; capital mais endividada do país

\section{Maurício Requião-Moreno}

Política como um jogo de cartas marcadas

Irregularidades na locação de veículos pelo governo do Estado e município, envolvendo locadoras que financiaram a campanha anterior de Cássio

Críticas à maquina do Estado; perda de popularidade do governador e Prefeito devido à corrupção, falcatruas; falta de lisura, de honestidade, de competência dos homens públicos

Falta de sensibilidade da atual gestão; desperdício de dinheiro público; dívida

Propaganda enganosa; edição de depoimentos de populares

Ação violenta da polícia contra vendedores ambulantes

Degradação dos serviços públicos de Curitiba; falta de habitação; enchentes e inundações; relocações indevidas 
Carência dos serviços de saúde; falta de médicos, crítica ao Programa Mãe Curitibana; imperícia médica, mal atendimento, tratamento desumano em centros de saúde

Crítica à lei do IPTU (que aumenta a alíquota para 3\% e aplica efeito redutor, que pode ser retirado a qualquer momento) 